\title{
Distribution and habitat use of the crystal darter ( Crystallaria asprella) and spotted darter (Etheostoma maculatum ) in the Elk River, West Virginia
}

\author{
Elizabeth A. Osier \\ West Virginia University
}

Follow this and additional works at: https://researchrepository.wvu.edu/etd

\section{Recommended Citation \\ Osier, Elizabeth A., "Distribution and habitat use of the crystal darter ( Crystallaria asprella) and spotted darter (Etheostoma maculatum ) in the Elk River, West Virginia" (2005). Graduate Theses, Dissertations, and Problem Reports. 2189.}

https://researchrepository.wvu.edu/etd/2189

This Thesis is protected by copyright and/or related rights. It has been brought to you by the The Research Repository @ WVU with permission from the rights-holder(s). You are free to use this Thesis in any way that is permitted by the copyright and related rights legislation that applies to your use. For other uses you must obtain permission from the rights-holder(s) directly, unless additional rights are indicated by a Creative Commons license in the record and/ or on the work itself. This Thesis has been accepted for inclusion in WVU Graduate Theses, Dissertations, and Problem Reports collection by an authorized administrator of The Research Repository @ WVU. For more information, please contact researchrepository@mail.wvu.edu. 


\title{
Distribution and Habitat Use of the Crystal Darter (Crystallaria asprella) and Spotted Darter (Etheostoma maculatum) in the Elk River, West Virginia
}

\author{
Elizabeth A. Osier \\ Thesis submitted to the \\ Davis College of Agriculture, Forestry and Consumer Science \\ at West Virginia University \\ in partial fulfillment of the requirements \\ for the degree of \\ Master of Science \\ in \\ Wildlife and Fishery Resources
}
Stuart A. Welsh, Ph.D., Chair
Dan Cincotta, MS
J. Todd Petty, Ph.D.
Division of Forestry
Morgantown, West Virginia
2005

Keywords: darter zoogeography, stream fishes, habitat use, Percidae 


\title{
Abstract \\ Distribution and Habitat Use of the Crystal Darter (Crystallaria asprella) and Spotted Darter (Etheostoma maculatum) in the Elk River, West Virginia
}

\section{Elizabeth A. Osier}

\begin{abstract}
Crystal darters (Crystallaria asprella) and spotted darters (Etheostoma maculatum) have disjunct distributions within the Mississippi River drainage. In West Virginia, both species are restricted to a single drainage (the Elk River). Little information exists on the distribution and habitat use of crystal and spotted darters in the Elk River. I surveyed the Elk River between Sutton and Charleston, West Virginia, and documented distributions of crystal and spotted darters, as well as habitat use and habitat availability data. Two crystal darters were collected during 20 sampling occasions from 2002 to 2004. Spotted darters were documented at 9 sites; habitat use data were collected at 3 sites via snorkeling. Spotted darters primarily used glide habitats (transitional areas between tails of pools and heads of riffles) with large unembedded substrate $(>20 \mathrm{~cm})$ and moderate velocities $(13$ to $51 \mathrm{~cm}$ sec-1). My observations support the rarity of crystal darters within the Elk River, but good habitat (based on habitat commonly used by crystal darters in other river systems) is available in the Elk River. Previous studies found large rocks and fast riffles as important spotted darter habitat. Spotted darters in the Elk River were associated with large rocks within glide habitats and were rarely found in riffles. Crystal and spotted darters are benthic habitat specialists; population persistence of these Elk River darters may be linked to stream sedimentation.
\end{abstract}




\section{Dedication}

I would like to dedicate the work represented by this thesis to my parents. It goes without saying that I could not have made it here were it not for your support. I am truly grateful for the drive and determination you instilled in me through out my upbringing. Thank you for always encouraging me to work harder and to be a better person. I love you. 


\section{Acknowledgements}

I would like thank the members of my graduate committee, Dr. Stuart Welsh, Dr. Todd Petty, and Dan Cincotta for their assistance throughout my graduate research. I give special appreciation to Stuart for his patient guidance through this process. Additionally, I am grateful to all my fellow graduate students for their assistance in data collection, including Heather Hildebrand, Lara Hedrick, Zach Liller, Ken Sheehan, and Dave Wellman. I would like to thank our funding sources, the West Virginia Cooperative Fish and Wildlife Research Unit, U.S. Geological Survey, U.S. Fish and Wildlife Service, and West Virginia Division of Natural Resources.

I would also like to acknowledge my friends and family for their support. Chris Moats was a pillar of strength for me and a source of continuous encouragement. Finally, I could not have accomplished so much in my life were it not for the continued loving support of numerous

friends. Their support, through moves across the country and back again, has helped me keep my eye on the future and a smile on my face. 


\section{Table of Contents}

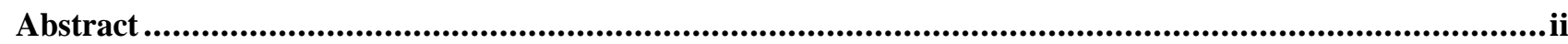

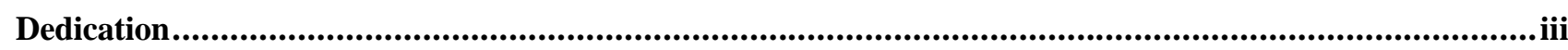

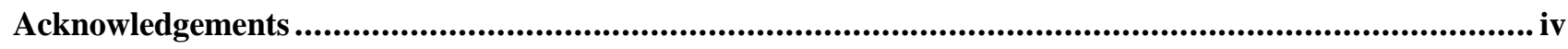

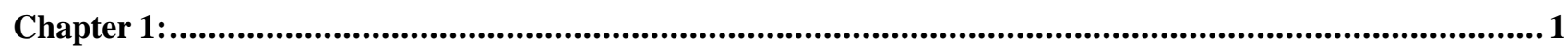

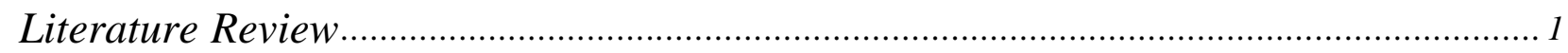

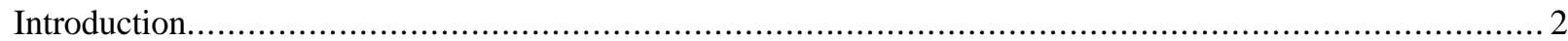

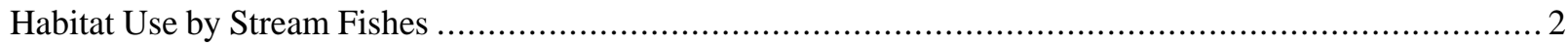

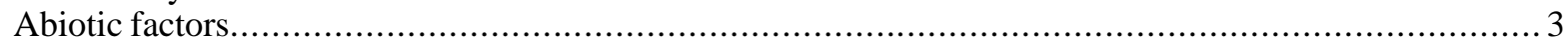

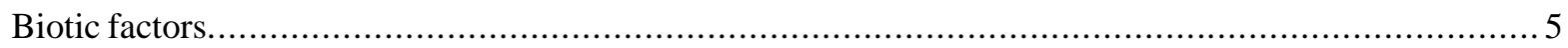

Life History and Habitat Use of the Crystal Darter (Crystallaria asprella) ....................................... 8

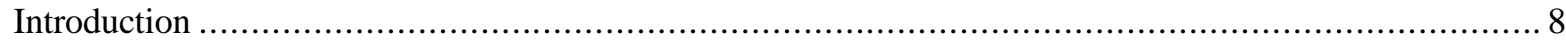

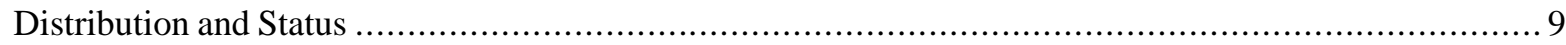

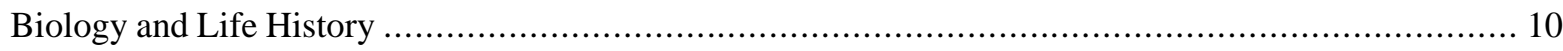

Life History and Habitat Use of the Spotted Darter (Etheostoma maculatum) ...................................... 13

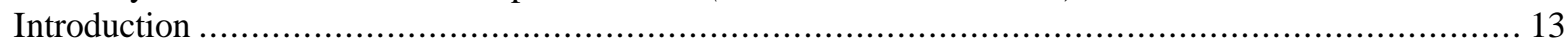

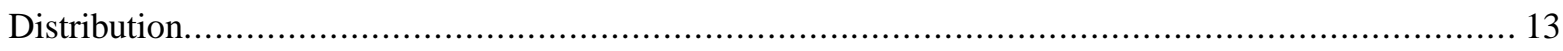

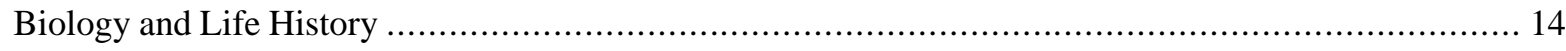

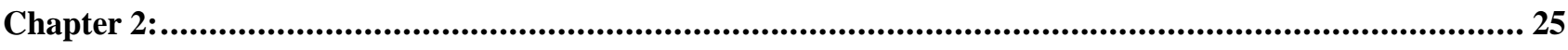

Distribution and habitat of Elk River crystal darters (Crystallaria asprella)................ 25

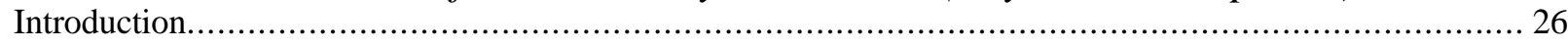

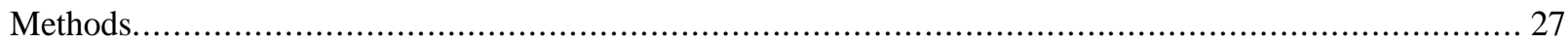

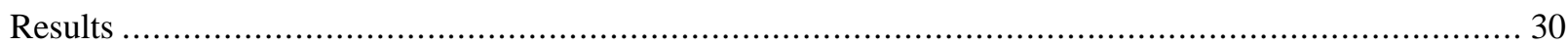

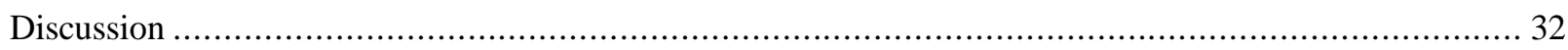

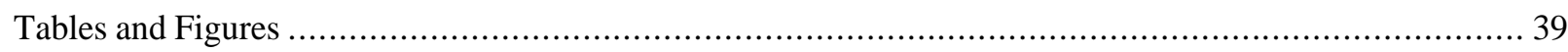

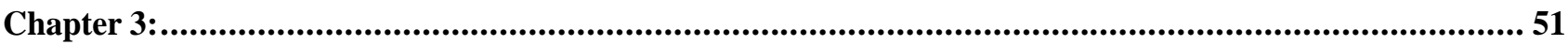

Habitat use of the Elk River spotted darter, Etheostoma maculatum........................... 51

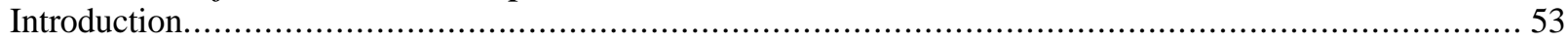

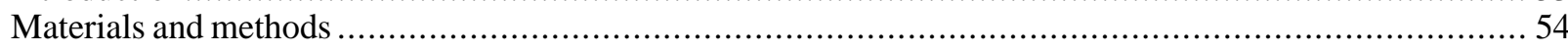

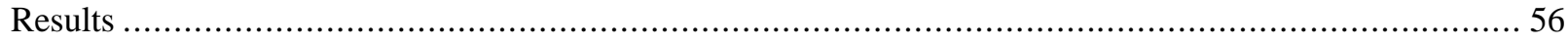

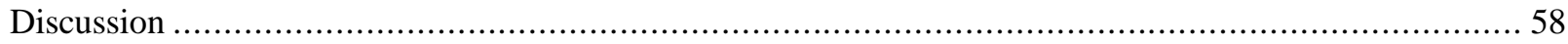

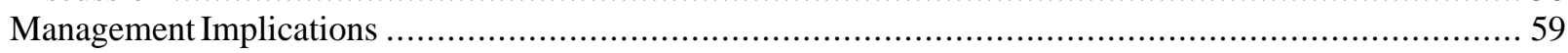

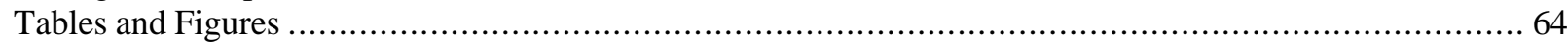


Chapter 1:

Literature Review 


\section{Introduction}

This thesis documents the geographic distribution and habitat use of two rare darters and includes three chapters: 1. an introduction and literature review of habitat use with emphasis on darters; 2. a study on the distribution and habitat of the Elk River crystal darter (Crystallaria asprella); and 3. a study on distribution and microhabitat use of spotted darters (Etheostoma maculatum). Crystal darters and spotted darters are distributed disjunctly within the Mississippi River watershed and inhabit a single drainage in West Virginia. Prior to my studies, Elk River crystal darters were known from only two locations representing eight individuals, and spotted darters were known from only two locations in the Elk River. A broader understanding of distributions and habitat use will enhance management and conservation of these rare species.

\section{Habitat Use by Stream Fishes}

Habitat use of stream fishes is influenced synergistically by abiotic factors (e.g., depth, velocity, temperature, substrate composition), biotic factors (competition, predation, foraging, resting and spawning), and phylogenetic constraints. Darters, a specious group of North American percids, exhibit diverse uses of habitat (Page 1983). As in most fishes, morphology and foraging behavior play complex roles in darter habitat use (Page and Swofford 1984). Some species of darters are habitat generalists, but most use one or more specific habitats (Page 1983). Abiotic and biotic factors can override habitat preferences by restricting habitat availability (Gorman 1988, Grossman et al. 1998).

Environmental and habitat variables across a range of spatial scales affect stream fish habitat use (Crook et al. 2001, Jackson et al. 2001). Stream habitat features consist of nested hierarchies, where small scale features nest within larger features (Hawkins et al. 1993). Several authors have defined spatial scales important to the study of stream fish habitat (Hawkins et al. 
1993, Kramer et al. 1997). Generally, large scales consist of a geographic region or an entire watershed and encompass a range of habitat variables that take into account geomorphic processes and major environmental conditions. At large scales, riffle/pool patterns can be semireplicated and biogeographic constraints can be considered (Jackson et al. 2001). Intermediate scales describe the habitat type or channel unit, such as a riffle or pool. Habitat units are relatively homogeneous and can be qualitatively determined (Hawkins et al. 1993, Kramer et al. 1997). Finer scales describe microhabitats that are typically differentiated quantitatively using habitat variables (Kramer et al. 1997). Microhabitats are considered to be the space used by an organism within its "normal daily range" (Kramer et al. 1997). The resolution of microhabitats may be determined by the researcher; however as scale decreases, habitat and environmental heterogeneity also decrease. Therefore, the effects of environmental differences are not easily detected (Jackson et al. 2001). This review will primarily address habitat use on intermediate and fine scales.

\begin{abstract}
Abiotic factors
Stream fishes use habitat on many interrelated dimensions. Fish ecologists commonly perceive depth, current velocity and substrate as important habitat features (Schlosser 1982). Water temperature is also an important influence on fish habitat use (Whiteside and McNatt 1972). Variations among these factors interact to determine abiotic habitat characteristics. Additionally, other physiochemical factors that approach or exceed tolerance limits influence fish habitat use.
\end{abstract}

Water depth and current velocity are interrelated factors that influence fish habitat use and are determined, in part, by channel morphometry and substrate deposition (Allan 1995). The influence of water depth and current velocity on habitat use is, in part, linked to fish morphology 
(Matthews 1985, Power et al. 1988, Winemiller 1992, Allan 1995). Many darter species inhabit shallow riffles, though some larger bodied species, including members of the genus Percina, use deeper pool habitats (Page 1983). Body morphologies of riffle-dwelling darters are adapted to swift velocities (Page and Swofford 1984, Matthews 1985). Bain et al. (1988) found that depth and velocity were the primary habitat variables affecting fish distribution in a river with variable flow. Matthews et al. (1982) found that current velocity was the largest overlapping microhabitat feature among three darter species in the Upper Roanoke River drainage. However, the roles of water depth and current velocity in stream fish habitat use cannot be clearly separated due to the interrelatedness of these variables.

Substrate provides habitats for foraging, reproduction, and shelter from predators and velocity. Variability in substrate creates habitat heterogeneity and available habitats for benthic darters. Darters are morphologically adapted to use a wide range of substrates (Page and Swofford 1984) and many species have specific requirements for the substrate particle size (Page 1983, Stauffer et al. 1996), such as Ammocrypta's use of sand. Substrate heterogeneity also creates areas of low velocity which fish, especially darters, use as "velocity shelters" (Harding et al. 1998).

Stream water temperature is affected by many factors including substrate, water depth and current velocity which create small scale temperature gradients that influence habitat of stream fishes (Whiteside and McNatt 1972). Fishes are affected physiologically by water temperature (Jobling 1981) and often alter habitat use in response to temperature changes. Hlohowskyj and Wissing (1985) found that critical thermal maximum of darters can shift seasonally. Interspecific variation in thermal tolerance, in addition to seasonal shifts, results in longitudinal separation of the distribution of darters along a stream gradient (Ingersoll and 
Claussen 1984). Variation in temperature acclimation rates can also determine whether darters use riffles or pools (Hlohowskyj and Wissing 1985, Ingersoll and Claussen 1984).

\section{Biotic factors}

Fishes often use different habitats for spawning, foraging and resting. Fish species, especially darters, have adapted behaviorally and morphologically to exploit habitat characteristics and allow for coexistence (Smart and Gee 1979, Page and Swofford 1984). However, interspecific interactions, such as competition and predation, also determine fish habitat use (Ross 1986). Limiting resources create competition, causing species' to alter habitat use (Scheoner 1974). Also, avoidance of predation strongly influences the behavior and habitat use of stream fishes (Werner et al. 1983, Schlosser 1987).

Habitats used during spawning periods often differ from those used during other periods. Because darters live in close association with the bottom, most spawn on substrate or vegetation (Winn 1958). Substrate type (for egg attachment; Page 1985) and current velocity (for egg aeration and stability; e.g. Etheostoma maculatum, Raney and Lachner 1939, Winn 1958) are important factors influencing spawning habitat. Darters use substrate by either burying eggs (exhibited by all Percina and Ammocrypta) or by attaching adhesive eggs to substrate including rocks, plants or woody debris (Page 1985). Winn (1958) noted that species with complex reproductive behavior use slower current than those with generalized behavior.

Foraging habitats, in part, are determined by body morphology (Winemiller 1992) and prey availability (Petty and Grossman 1996). Because darters feed primarily on benthic insects (Forbes 1880), their foraging habitat does not generally differ from other habitats. Darters with small body size forage under and between rocks (Page and Swofford 1984). Head morphology and mouth position differ among darters allowing for differential foraging mechanisms (Page 
1985) and optimal foraging efficiency in riffles (Page and Swofford 1984). Darters eat from the top, sides and bottom of rocks, and by over turning rocks (Page 1983, Welsh and Perry 1998).

The use of habitat for "resting" by stream fishes is a means of energy conservation. Facey and Grossman (1992) found that energetic constraints of habitat were more important for water column species than for benthic fish, such as darters. They hypothesized that morphological features reduce the importance of energetic cost of habitat for benthic species. Harding et al. (1998) showed that microhabitat velocity shelters created by heterogeneous substrate acts as refugia for darters. Daniels (1989) suggested that energy conservation could be one reason eastern sand darters (Ammocrypta pellucida) exhibit burrowing behavior (though it may not be the only reason).

Competition, for both space and food resources, can greatly alter habitat use by stream fishes. Competition occurs when two species interact for the use of a resource and one species impedes another species' use of the same resource (interference) or when the interaction reduces the fitness of one of the species (exploitative, Schlosser 1987, Grossman and Freeman 1987). Interference competition, in conjunction with other factors, usually results in resource partitioning (Schoener 1969). However darters' use of benthic habitats is due, in part, to phylogenetic history (Grossman and Freeman 1987). Resource partitioning among stream fishes is often based on food resources (Ross 1986), however Grey et al. (1997) concluded that resource partitioning in a guild of darters was due to other spatial requirements. Additionally, Ingersoll and Claussen (1984) found that interspecific avoidance was the overriding factor in selection of thermal habitat when fantail darters (Etheostoma flabellare) and johnny darters (Etheostoma nigrum) co-occurred. Darters' high diversity of foraging mechanisms reduces competition for prey (Page 1983), but because some species are generalists, while others are 
specialists, interspecific interactions result in competition for space. Additionally, many species of darters exhibit territoriality (Winn 1958) and aggressive behavior does influence habitat use in some darter communities (e.g. Kessler and Thorp 1993).

Predation risk influences habitat use of stream fishes, often forcing potential prey species into suboptimal foraging habitat (e.g. Power 1984). Predators also influence the use of depth and substrate of prey species (Schlosser 1987, Schlosser 1988). Schlosser (1987) reported that largemouth bass forced small species, including darters, from pool to riffle habitat. Small darters, whose major predators are often centrarchids (Page 1983, Greenberg 1991), hide within the substrate and avoid predators (Page and Swofford 1984). Despite the threat of avian predation in shallow waters (Schlosser 1987), small-bodied darters avoid both avian and aquatic predation through the use of substrate. Within deeper pool habitats, larger bodied Percina, avoid predation by remaining near the bottom (Greenberg 1991).

Seasonal habitat shifts of stream fishes are due to behavior (e.g. spawning) or environmental variables (e.g. temperature and flow). Additionally ontological changes, such as juvenile to adult, typically result in habitat shifts. Winn (1958) noted that most darters exhibit reproductive migration, but otherwise use a relatively small area. Deep water species move to shallower regions, while riffle species move to deeper, slower habitats (Winn 1958). Mundahl and Ingersoll (1983) found that johnny darters (E. nigrum) moved little outside of the reproductive season, but fantail darters (E. flabellare) exhibited considerable early autumn upstream movement, possibly seeking better quality habitat. Stream flow changes, which occur seasonally or within smaller time frames, can be highly variable and unpredictable (Bain et al. 1988) and can drastically change the physical habitat of fishes (Harding et al 1998). Stauffer et al. (1996) found that seasonal shifts in darter habitat use were related to environmental 
fluctuations, such as high water levels. However, some darter species may exhibit habitat shifts based on endogenous circannual rhythms rather than environmental conditions (e.g., photo period, Ingersoll and Claussen 1984). Ross et al. (1992) found that bayou darters (Etheostoma rubrum) increased use of cover during cold water conditions possibly because low temperatures reduce a fish's ability to withstand variable water velocities. Additionally, the absence of vegetation in winter months could result in the use of different foraging habitat (White and Aspinwall 1984). Ontological shifts are, in part, related to flow because juvenile fish are more highly affected by the high between-year flow variability than adults (Schlosser 1985). Habitats of juvenile darters are typically shallower and slower than those of adults (Winn 1958, Page 1983).

Darters are a complex, highly specialized group of fishes. Multiple mechanisms typically influence habitat use of darters. Because many darters exhibit specific habitat requirements, several species are threatened by habitat alterations (Connelly et al. 1999, Mattingly and Galat 2002, Wood and Raley 2000). For instance, sedimentation associated with land use practices threaten darter habitat as it fills interstitial spaces (Mattingly and Galat 2002) and chokes aquatic vegetation (Connelly et al. 1999). Management actions can reduce negative impacts to sensitive darter species such as protection of riparian areas (Jones et al. 1999) or entire watersheds (Freeman and Freeman 1994). Studying and defining habitat use can help researchers and managers develop effective darter conservation programs.

\section{Life History and Habitat Use of the Crystal Darter (Crystallaria asprella)}

\section{Introduction}

The crystal darter, Crystallaria asprella, is a rare species known to inhabit medium to large rivers. For a darter, it is moderately sized and it is physically distinctive due to its 
translucent body with three to four dorsal saddles and a mid-lateral stripe of fused ovoid blotches (Page 1983, Etnier and Starnes 1993, Keuhne and Barbour 1983). David Starr Jordan first described the crystal darter in 1878 from a tributary of the Mississippi River in Illinois, naming it Pleurolepis asprellus (Jordan 1878). It was later analyzed with sand darters (genus Ammocrypta) because of an elongate shape, translucent skin and musculature, and a single anal spine characteristic of the genus (Simons 1991). Presently, the crystal darter comprises the monotypic genus Crystallaria based on Simons' (1991) sister relationship between Crystallaria asprella and a larger monophyletic group of Percina, Etheostoma and the Ammocrypta.

\section{Distribution and Status}

In the late 1800 s and early 1900 s, the crystal darter, was distributed widely within Mississippi River drainage from Mississippi west to southeastern Oklahoma, north to southern Minnesota and southeast to Ohio; and in Gulf Coast drainages from the western panhandle of Florida to Mississippi (Page 1980, Keuhne and Barbour 1983, Grandmaison et al. 2003). The crystal darter's distribution has decreased dramatically during the last century (Hatch 1997, Etnier and Starnes 1993). Stable populations occur in Alabama, Louisiana and Arkansas (George et al. 1996, Sheppard et al. 1999, Hatch 1997) while populations in Minnesota and Wisconsin are restricted (Becker 1983, Hatch 1997). Populations within Indiana, Ohio, Illinois, Kentucky and Tennessee are considered extirpated (Hatch 1997).

The only recently documented crystal darter population in the Ohio River drainage occurs in the Elk River, West Virginia. It was first collected 1.6 river km below Mink Shoals in November of 1980 (Cincotta and Hoeft 1987). Previous to 2002, a total of eight individuals were collected during sampling efforts at or near Mink Shoals and another site approximately 18 river km upstream near Clendenin, West Virginia. 
Wood and Raley (2000) and Morrison et al. (2004) reported that the crystal darter population within the Elk River, WV, is genetically distinct from populations in the Saline River, AR; Zumbro River, MN; Cahaba River, AL/Pearl River, MS. Action is required to protect this evolutionarily significant lineage from continued anthropogenic impacts to the Elk River drainage (Morrison et al. 2004, Wood and Raley 2000). The authors suggest that the Elk River crystal darter be protected by the Endangered Species Act due to its unique genetic status.

\section{Biology and Life History}

While ecological descriptions of the crystal darter are numerous (Etnier and Starnes 1993, Robison and Buchanan 1988, Keuhne and Barbour 1983, Becker 1983, Clay 1975, Trautman 1981, Miller and Robison 1973, Page 1983; Grandmaison et al. 2003), most are based on pre-1940 data (Clay 1975, Etnier and Starnes 1993, Trautman 1981). Due to its rarity, little research exists on the natural history of this species (Lutterbie 1979, Hatch 1997, Etnier and Starnes 1993, Keuhne and Barbour 1983). Few direct observations exist of the crystal darter in its native habitat (George et al. 1996, Becker 1983). Crystal darters are often collected at night (Cincotta and Hoeft 1987, Shepard et al. 1999), but George et al. (1996) successfully collected crystal darters during the day. Becker (1983) speculates that they remain in deeper pools during the day, which makes sampling difficult. They probably move into shallow riffles at night where they are more easily detected (Becker 1983). However, they may inhabit riffles during the day, but are able to evade capture; therefore night sampling is more successful (D. Cincotta, pers. comm.). Currently, we know little about diurnal habits of crystal darters.

Adult crystal darters range in maximum standard length from $99 \mathrm{~mm}$ (George et al. 1996) to $144 \mathrm{~mm}$ (Lutterbie 1979). Lutterbie (1979) concludes that crystal darters in Wisconsin have a life expectancy of three years, while George et al. (1996) found the maximum age of crystal 
darters in the Saline River, Arkansas to be two years. Etnier and Starnes (1993) reported a life expectance of 2 to 4 years. George et al. (1996) suggested that the disparity in size and life expectancy between individuals from southern and northern populations may be due to environmental differences. He suggested that Saline River populations might mature before age one and begin reproducing at an earlier age than northern populations, resulting in shorter life spans.

\section{Habitat}

While there are few documented observations of Crystallaria asprella habitat use, it is typically collected from 0.5 to $1.5 \mathrm{~m}$ depths in moderate to strong velocities over sand and gravel substrate (Becker 1983, Robison and Buchanan 1988, Shepard et al. 1999, Simon et al. 1992). Current velocities in crystal darter habitat range from an average of $30 \mathrm{~cm} / \mathrm{sec}$ in the Mississippi River (Hatch 1997) to an average of $70 \mathrm{~cm} / \mathrm{sec}$ from the Saline River, Arkansas (George et al. 1996; see Table 1 of Chapter 2). George et al. (1996) collected crystal darters in the Saline River, Arkansas, over predominantly gravel substrate, with small cobble and patches of sand, while Hatch (1997) collected individuals over coarse sand and gravel with 30\% to 40\% embedded cobble and boulder in the Mississippi River. Swift currents in crystal darter habitat account for the reported "clean swept" substrate and lack of silt (Etnier and Starnes 1993, Simon et al. 1992). Additionally, crystal darters are not associated with debris or vegetation (George et al. 1996, Shepard et al. 1999).

In captivity, crystal darters burrow into sand, where only their eyes protrude (Miller and Robison 1992). Crystal darters may exhibit similar habitat use in natural environments. Similar burrowing behavior was documented for the genus Ammocrypta (Page 1983). Darters may 
burrow to avoid predation or as an ambush foraging tactic (Trautman 1981). However, Daniels (1989) suggested that sand darters burrow in sandy substrates for stability in turbulent velocities.

\section{Reproduction}

Little is known about reproductive habits of crystal darters. Breeding tubercles occur on the anal and pelvic fin rays of mature males (George et al. 1996, Page 1983, Lutterbie 1979). Crystal darters in the Mississippi River developed breeding tubercles from late autumn to winter suggesting a spring spawn (Lutterbie 1979, Keuhne and Barbour 1983). George et al. (1996) reported that crystal darters in the Saline River, Arkansas, developed tubercles as early as late October. The reproductive season occurs in the late winter or early spring (January through midApril), based on both tubercle and testicular development. Additionally, George et al. (1996) reported minute breeding tubercles on females. George et al. (1996) also reported evidence of two different size classes of ova in female crystal darters, suggesting multiple spawnings per reproductive cycle.

Only one account of crystal darter spawning has been documented. Simon et al. (1992) reported that crystal darters left the mainstem Tallapoosa River, Alabama, in late February and moved into a "moderately swift" 60 to $90 \mathrm{~cm}$ deep side channel riffle with gravel substrate. Spawning occurred over the course of a week in water temperatures from 1.6 to $12.8^{\circ} \mathrm{C}$. During spawning and egg deposition, the female was partially submerged in sand and "mounted" by one or several males.

\section{Foraging}

With few direct observations of crystal darters, foraging behavior and use of habitat are poorly understood; however diet data provides insights on foraging habitat. Miller and Robison (1992) suggested that crystal darters burrow as an ambush foraging tactic. Daniels (1989) 
concluded that ambush foraging is not supported for sand darters (Ammocrypta sp.) based on body shape, mouth shape and diet. Though crystal darter morphology differs slightly from sand darters, their diets are very similar. Midge larvae and caddisfly larvae are most abundant in crystal darter diets (Lutterbie 1976, Hatch 1997). Lutterbie (1976) reported that midges comprised the largest proportion of biomass. Hatch (1997) found that caddisflies contributed the greatest amount of biomass, but midges were more abundant in the diet. Hatch (1997) also noted that water mites (Hydrachnidae) were consumed in substantial quantities, though the contribution to biomass was negligible. Daniels (1989) suggests that these items originate from drift or sandy substrate and are defenseless against fish predators, therefore, there is no need for ambush predation. Hatch (1997) likewise suggested that, rather than remaining stationary to ambush prey, crystal darters actively forage in a variety of habitats. While embedded in sand, however, crystal darters may enjoy a velocity break adjacent to macroinvertebrate drift, a strategy similar to salmonids in eddy edges.

\section{Life History and Habitat Use of the Spotted Darter (Etheostoma maculatum)}

\section{Introduction}

The spotted darter, Etheostoma maculatum, is a rare species with a disjunct distribution within the Ohio River drainage. This member of the sub-genus Nothonotus originally included populations from the Upper Ohio River, Cumberland River and Tennessee River systems.

However, three geographically separated sub-species (E. m. maculatum, E. m. sanguifluum, and E. m. vulneratum) described by Zorach and Raney (1967) were elevated to species status by Etnier and Williams (1989).

\section{Distribution}


The spotted darter's disjunct distribution ranges from northwest Pennsylvania and southwest New York to central Kentucky, and north to north-central Indiana (Etnier 1980). Populations occur in Pennsylvania and New York in the French Creek drainage of the Allegheny River watershed (Raney and Lachner 1939, Etnier 1980, Stauffer et al. 1996). In Ohio, a spotted darter population occurs in Big Darby Creek (Trautman 1981). Etnier (1980) noted that the population in the Wabash River drainage in Indiana is probably extirpated. Baker et al. (1985) reported collections of spotted darters between 1976 and 1984 in the Blue River, a tributary of the Ohio River in southern Indiana. In Kentucky, the spotted darter occurs in Russell Creek of the Green River watershed (Kessler 1994, Kessler and Thorp 1993) and the North Fork of the Kentucky River (Burr and Warren 1986). In West Virginia, spotted darters are restricted to the Elk River drainage of the lower Kanawha River system (Cincotta et al. 1986).

\section{Biology and Life History}

The spotted darter, drab olive in color with horizontal lines along the sides, has a narrow head, sharp snout and rounded caudal fin (Zorach and Raney 1967). Males have red spots encircled in black on the side of the body and, during spawning, develop a bluish-green breast and anal and pelvic fins with white margins (Raney and Lachner 1939, Zorach and Raney 1967, Page 1983). Fins and lateral body of females are primarily dusky with faint horizontal lines along sides (Zorach and Raney 1967).

\section{Habitat}

Spotted darters are typically collected from riffles containing gravel or cobble substrate (Kessler and Thorp 1993, Stauffer et al. 1996, Trautman 1981). Kessler and Thorp (1993) postulated that laterally-compressed bodies of spotted darters promoted use of imbricate substrates. Spotted darters are often associated with large loose substrate with interstitial spaces 
(Kessler and Thorp 1993). Spotted darters used large pebble (2-16 mm) in Russell Creek, Kentucky (Kessler et al. 1995) and cobble/boulder substrate $\left(25\right.$ to $\left.100 \mathrm{~cm}^{2}\right)$ in French Creek, Pennsylvania (Stauffer et al. 1996). Kessler et al. (1995) noted a shift in habitat use from rough substrate (high size variability) to smoother substrates (lower size variability) from July to October. Additionally, Kessler and Thorp (1993) observed that spotted darters were "never found in areas with silt covered rocks and only rarely occurred where substrates were packed."

Spotted darters in Russell Creek, Kentucky, and French Creek, Pennsylvania, were found in water approximately $20 \mathrm{~cm}$ deep with a mean velocity (at $60 \%$ of depth) ranging from 40 to $60 \mathrm{~cm} / \mathrm{sec}$ and a bottom velocity of approximately $14 \mathrm{~cm} / \mathrm{sec}$ (Kessler and Thorp 1993, Kessler et al. 1995, Stauffer et al. 1996). Water velocities associated with spotted darters in Russell Creek and French Creek were swifter (Kessler et al. 1995) and as deep as average available habitat (Kessler et al. 1995, Stauffer et al. 1996). Kessler et al. (1995) found spotted darters in Russell Creek used deeper habitat with greater velocity in July than in October. Due to higher water levels, available habitat in July was deeper with greater velocity than in October, resulting in an apparent shift in habitat use (Kessler et al. 1995). Stauffer et al. (1996) reported spotted darters as generalists in the use of depth.

\section{Reproduction}

In Pennsylvania, spawning occurred between late May and late June at water temperatures of approximately $17.8^{\circ} \mathrm{C}$ (Raney and Lachner 1939). While facing upstream, males guarded nests under stacked or overlapping cobble and large gravel. Nests were spaced approximately $1.2 \mathrm{~m}$ apart at 15 to $60 \mathrm{~cm}$ depths. Eggs were deposited in a wedge shape on the underside of the rock. Not all eggs were deposited in one spawning episode. Likewise, eggs in ovaries of females differed in stage of maturity, suggesting multiple spawning per season 
(possibly as many as four). Nesting males and spawning females foraged during the spawning period. Though nest predation was not observed, eggs found in male stomachs support cannibalization. Raney and Lachner (1939) did not report incubation period or parental care.

\section{Age \& Growth}

Limited research exists on age and growth of spotted darters. Raney and Lachner (1939) did not determine maximum age, but found that males and females spawn at age 2. Males grow faster than females and are consequently larger. On average males at age 2 were $48 \mathrm{~mm}$ standard length (SL) while females were 44 mm SL (Raney and Lachner 1939).

\section{Food}

The head shape and mouth orientation allow spotted darters to feed off rock surfaces (Kessler 1994, Kessler et al. 1995). With a laterally compressed body, narrow pointed snout and terminal mouth, spotted darters fit into crevices under and between rocks (Kessler and Thorp 1993). Kessler (1994) notes that the spotted darters' ability to feed from numerous rock surfaces suggests that it feeds opportunistically. Diet studies also support opportunistic foraging. Diet items of spotted darters are similar to other species in the sub-genus Nothonotus, where primary items include Chironomidae and Simuliidae larvae (Kessler 1994, Gray et al. 1997) as well as water mites, mayflies, stoneflies and caddisflies (Kessler 1994).

Grey et al. (1997) and Hansen et al. (1986) reported seasonal preferences in spotted darter diets. Seasonal shifts in spotted darter diets are associated with shifts in habitat use and prey availability (Kessler 1994, Grey et al. 1997). Kessler (1994) found that spotted darters consumed more food items in October than in July; however, in July, a greater diversity of taxa was consumed. An increase in chironomids and stoneflies in spotted darter diets in October probably resulted from a seasonal decrease of mayfly and caddisfly abundance (Kessler 1994). 
Additionally, the dramatic differences in flow between July and October may explain differences in prey availability and abundance (Kessler 1994). Hansen et al. (1986) also found a higher diversity of prey items later in the summer season. Gray et al. (1997) found that female spotted darters consumed significantly more prey than males during the spawning period. Females and males differ in habitat use during the spawning period (Raney and Lachner 1939, Kessler and Thorp 1993) which could explain dietary differences. Additionally, male nest guarding and territoriality (Raney and Lachner 1939) reduce foraging time.

\section{Community}

Stauffer et al. (1996) found that microhabitat segregation is "critically" important in darter niche divergence. Gray et al. (1997) observed that resource partitioning among darters is due to spatial requirements rather than foraging. Stauffer et al. (1996) found that spotted darters occupied significantly different habitat than Etheostoma zonale, Etheostoma caeruleum, Etheostoma camurum and Percina caprodes, but not significantly different habitat than $E$. flabellare, Etheostoma blennioides, Etheostoma tippecanoe and Etheostoma variatum. In Kentucky and Pennsylvania, primary differences between E. maculatum and co-existing species are water velocities and substrate size (Kessler et al. 1995, Stauffer et al. 1996). Inflexibility in resource use may create microhabitat limitations for spotted darters, as was evident in territoriality between E. maculatum and Etheostoma bellum (Kessler and Thorp 1993).

\section{Literature Cited}

Allan, J. D. 1995. Stream ecology: structure and function of running waters. Chapman \& Hall, London, UK.

Bain, M.B., J. T. Finn, and H. E. Booke. 1988. Streamflow regulation and fish community structure. Ecology 69: 382-392. 
Baker, C., B. Forsyth, T. Wiles, D. B. Abrell. 1985. Rediscovery of the spotted darter, Etheostoma maculatum, in Indiana waters: Blue River; Crawford, Harrison and Washington Counties; Ohio River Drainage, USA. Indiana Acad. of Sci. 94: 603-605.

Becker, G. C. 1983. Fishes of Wisconsin. The Univ. of Wisconsin Press, Madison.

Burr, B. M. and M. L. Warren. 1986. Distributional atlas of Kentucky fishes. Kentucky Nature Preserves Commission, Frankfort.

Cincotta, D. A. and M. E. Hoeft. 1987. Rediscovery of the crystal darter, Ammocrypta asprella, in the Ohio River Basin. Brimleyana 13: 133-136.

Cincotta, D. A., R.L. Miles, M. E. Hoeft, and G. E. Lewis. 1986. Discovery of Noturus eleutherus, Noturus stigmosus and Percina peltata in West Virginia, with discussions of other additions and records of fishes. Brimleyana 12: 101-121.

Clay, W. M. 1975. The Fishes of Kentucky. Kentucky Department of Fish and Wildlife Resources, Frankfort.

Connelly, W. J., D. J. Orth, R. K. Smith. 1999. Habitat of the riverweed darter, Etheostoma podostemone Jordan, and the decline of riverweed, Podostemum ceratophyllum, in the tributaries of the Roanoke River, Virginia. J. Freshwat. Ecol. 14: 93-102.

Crook, D. A., A. I. Robertson, A. J. King. 2001. The influence of spatial scale and habitat arrangement on diel patterns of habitat use by two lowland river fishes. Oecologia 129: 525-533.

Daniels, R. A. 1989. Significance of burying in Ammocrypta pellucida. Copeia 1989: 29-34.

Etnier, D. A. and W.C. Starnes. 1993. The Fishes of Tennessee. The Univ. of Tennessee Press, Knoxville.

Etnier, D. A. 1980. Etheostoma maculatum Kirtland Spotted darter. Page 664. in D. S. Lee, C. R. Gilbert, C. H. Hocutt, R. E. Jenkins, D. E. McAllister, J. R. Stauffer, Jr. editors, Atlas of North American freshwater fishes. N.C. State Mus. Nat. Hist., Raleigh.

Etnier, D. A. and J. D. Williams. 1989. Etheostoma (Nothonotus) wapiti (Osteichthyes: Percidae), a new darter from the southern bend of the Tennessee River system in Alabama and Tennessee. Proc. Biol. Soc. Wash. 102(4): 987-1000.

Facey, D. E. and G. D. Grossman. 1992. The relationship between water velocity, energetic costs and microhabitat use in four North American stream fishes. Hydrobiologia 239: 1-6.

Forbes, S. A. 1880. The food of darters. Amer. Nat. 13: 807-816. 
Freeman, B. J. and M. C. Freeman. 1994. Habitat use by an endangered riverine fish and implications for species protection. Ecol. of Freshwat. Fish 3: 49-58.

George, S. G., W. T. Slack, and N. H. Douglas. 1996. Demography, habitat, reproduction and sexual dimorphism of the Crystal darter, Crystallaria asprella (Jordan), from southcentral Arkansas. Copeia 1996: 68-78.

Gorman, O. T. 1988. The dynamics of habitat use in a guild of Ozark minnows. Ecol. Monog. 58: $1-18$.

Grandmaison, D., J. Mayasich, and D. Etnier. 2003. Crystal darter status assessment report. U. S. Fish and Wildlife Service. Technical Report \# NRRI/TR-2003/19. <http://midwest.fws.gov/endangered/fishes/crda-sa.pdf> (18 August 2004)

Gray, E., J. M. Boltz, K. A. Kellogg, and J. R. Stauffer, Jr. 1997. Food resource partitioning by nine sympatric darter species. Trans. Am. Fish. Soc. 126: 822-840.

Greenberg, L. A. 1991. Habitat use and feeding behavior of thirteen species of benthic stream fishes. Environ. Biol. Fish.31: 389-401.

Grossman, G. D. and M. C. Freeman. 1987. Microhabitat use in a stream fish assemblage. J. of Zool., Lon. 212: 151-176.

Grossman, G. D., R. E. Ratajczak, Jr., M. Crawford and M. C. Freeman. 1998. Assemblage organization in stream fishes: effects of environmental variation and interspecific interactions. Ecol. Monog. 68: 395-420.

Hansen, M. J., S. P. Gloss, B. L. Peckarsky. 1986. Predator species richness and prey population variability: effects on diets of benthic stream fishes. Amer. Midl. Nat. 115: 63-72.

Harding, J. M., A. J. Burky, and C. M. Way. 1998. Habitat preferences of the rainbow darter, Etheostoma caeruleum, with regard to microhabitat velocity shelters. Copeia 1998: 988997.

Hatch, J. T. 1997. Resource utilization and life history of the Crystal darter, Crystallaria asprella (Jordan), in the Lower Mississippi River, Minnesota. Minnesota Natural Heritage and Nongame Wildlife Research Program, St Paul.

Hawkins, C. P. and 10 others. 1993. A hierarchical approach to classifying stream habitat features. Fisheries 18(6): 3-12.

Hlohowskyj, I. and A. M. White. 1983. Food resource partitioning and selectivity by the greeenside, rainbow and fantail darters (Pisces: Percidae). Ohio J. Sci. 83: 201-208. 
Hlohowskyj, I. and T. E. Wissing. 1985. Seasonal changes in the critical thermal maxima of fantail (Etheostoma flabellare), greenside (Etheostoma blennioides), and rainbow (Etheostoma caeruleum) darters. Can. J. Zool. 63: 1629-1633.

Hlohowskyj, I. and T. E. Wissing. 1986. Substrate selection by fantail (Etheostoma flabellare), greenside (E. blennioides) and rainbow (E. caeruleum) darters. Ohio J. Sci. 86: 124-129.

Hubert, W.A., D.D. Harris \& T.A. Wesche. 1994. Diurnal shifts in use of summer habitat by age0 brown trout in a regulated mountain stream. Hydrobiologia 284: 147-156.

Hynes, H.B.N. 1970. The ecology of running waters. Liverpool University Press, U.K.

Ingersoll, C. G. and D. L. Claussen. 1984. Temperature selection and critical thermal maxima of the fantail darter, Etheostoma flabellare, and the johnny darter, E. nigrum, related to habitat and season. Environ. Biol. Fish. 11:131-138.

Jackson, D. A. P. R. Peres-Neto, and J. D. Olden. 2001. What controls who is where in freshwater fish communities - the roles of biotic, abiotic and spatial factors. Can. J. Fish. Aquat. Sci. 58: 157-170.

Jenkins, R. E., E. A. Lachner, and F. J. Schwartz. 1972. Fishes of the central Appalachian drainages: their distribution and dispersal. Pages 43-117 in P. C. Holt, R. A. Patterson and J. P. Hubbard, editors. The distributional history of the biota of the southern Appalachians, Part III: Vertebrates. Res. Div. Monogr. 4. Va. Polytech. Inst. \& State Univ., Blacksburg.

Jobling, M. 1981. Temperature tolerance and the final preferendum - rapid methods for the assessment of optimum growth temperatures. J. Fish. Biol. 19: 439-455.

Jones, E. B. D., G. S. Helfman, J. O. Harper, \& P. V. Bolstad. Effects of riparian forest removal on fish assemblages in southern Appalachian streams. Con. Biol. 13: 1454-1465.

Jordan, D. S. 1878. A catalogue of fishes of Illinois. Ill. Nat. Hist. Surv. Bull. 2: 37-70.

Kerr, S. R. 1971. Prediction of fish growth efficiency in nature. J. Fish. Res. Bd. Can. 28: 809814.

Kessler, R. 1994. Diet of the spotted darter, Etheostoma maculatum (Pisces: Percidae): A threatened species in Kentucky. Trans. Ky. Acad. of Sci. 55: 28-31.

Kessler, R. K. and J. H. Thorp. 1993. Microhabitat segregation of the threatened spotted darter (Etheostoma maculatum) and closely related orangefin darter (E. bellum). Can. J. Fish. Aquat. Sci. 50: 1084-1091. 
Kessler, R., A. Casper, G. Weddle 1995. Temporal variation in microhabitat use and spatial relations in the benthic fish community. Amer. Midl. Nat.134: 361-370.

Keuhne, R. A. and R. W. Barbour. 1983. The American darters. Univ. of Kentucky Press, Lexington.

Kramer, D. L. R. W. Rangeley, L. J. Chapman. 1997. Habitat selection: patterns of spatial distribution from behavioral decisions. Pages 37-80 in J. J. Godin editor. Behavioural ecology of teleost fishes. Oxford Univ. Press, UK.

Lobb, M. D. and D. J. Orth. 1991. Habitat use by an assemblage of fish in a large warmwater stream. Trans. Amer. Fish. Soc.120: 65-78.

Lutterbie, G. W. 1976. The darters (Pisces:Percidae:Etheostomatinae) of Wisconsin. Dissertation, Univ. of Wisconsin, Stevens Point.

Lutterbie, G. W. 1979. Reproduction and age and growth in Wisconsin darters. Reports on the fauna and flora of Wisconsin 15: 1-44.

Matthews, W. J. 1985. Critical current speeds and microhabitats of the benthic fishes Percina roanoka and Etheostoma flabellare. Environ. Biol. Fish. 12: 303-308.

Matthews, W. J. 1998. Patterns in freshwater fish ecology. Chapman \& Hall, New York, NY.

Matthews, W. J., J. R. Bek and E. Surat. 1982. Comparative ecology of the darters Etheostoma podostemone, E. flabellare, Percina roanoka in the Upper Roanoke River drainage, Virginia. Copeia 1982: 805-814.

Mattingly, H. T. and D. L. Galat. 2002. Distributional patterns of the threatened Niaguana darter, Etheostoma nianguae, at three spatial scales, with implications for species conservation. Copeia 2002: 573-585.

Miller, R. J. and H.W. Robison. 1973. The fishes of Oklahoma. Oklahoma State Univ. Press, Stillwater.

Morrison, C. L., D. P. Lemarié, R. M. Wood, T. L. King. In Press. Phylogeographic analyses suggest multiple lineages of Crystallaria asprella (Percidae: Etheostominae). Conservation Genetics.

Mundahl, N. D., and C. G. Ingersoll. 1983. Early autumn movements and densities of Johnny (Etheostoma nigrum) and fantail (E. flabellare) darters in a southwestern Ohio stream. Ohio Acad. Sci. 83: 103-108. 
Page, L. M. 1980. Ammocrypta asprella (Jordan) Crystal darter. Page 615. in D. S. Lee, C. R. Gilbert, C. H. Hocutt, R. E. Jenkins, D. E. McAllister, J. R. Stauffer, Jr. editors, Atlas of North American freshwater fishes. N.C. State Mus. Nat. Hist., Raleigh.

Page, L. M. 1983. Handbook of darters. TFH Publications, Neptune City, NJ.

Page, L. M. 1985. Evolution of reproductive behaviors in percid fishes. Ill. Nat. Hist. Surv. Bull. 33: 275-295.

Page, L. M. and D. L. Swofford. 1984. Morphological correlates of ecological specialization in darters. Environ. Biol. Fish. 11: 139-159.

Petty, J. T. and G. D. Grossman. 1996. Patch selection by mottled sculpin (Pisces: Cottidae) in a southern Appalachian stream. Freshwat. Biol. 35: 261-276.

Power, M. E. 1984. Depth distributions of armored catfish: Predator-induced resource avoidance? Ecology 65: 523-528.

Power, M. E. and eight others. 1988. Biotic and abiotic controls in river and stream communities. J. N. Am. Benthol. Soc. 7: 456-479.

Raney, E. C. and E. A. Lachner. 1939. Observations on the life history of the spotted darter, Poecilichthys maculatus (Kirtland). Copeia 1939: 157-165.

Robison, H. W. and T. M. Buchanan. 1988. Fishes of Arkansas. The Univ. of Arkansas Press, Fayetteville.

Ross, S. T. 1986. Resource partitioning in fish assemblages: A review of field studies. Copeia 1986: 352-388.

Ross, S. T., J. G. Knight, S. David Wilkins. 1992. Distribution and microhabitat dynamics of the threatened bayou darter, Etheostoma rubrum. Copeia 1992: 658-671.

Schaefer, J. F, E. Marsh-Matthews, D. E. Spooner, K. B. Gido, W. J. Matthews. 2003. Effects of barriers and thermal refugia on local movement of the threatened leopard darter, Percina pantherina. Environ. Biol. Fish. 66: 391-400.

Schoener, T. W. 1974. Resource partitioning in ecological communities. Science 185: 27-38.

Schlosser, I. J. 1982. Fish community structure and function along two habitat gradients in a headwater stream. Ecol. Monog. 52: 395-414.

Schlosser, I. J. 1985. Flow regime, juvenile abundance, and the assemblage structure of stream fishes. Ecology 66: 1484-1490. 
Schlosser, I. J. 1987. The role of predation in age- and size-related habitat use by stream fishes. Ecology 68: 651-659.

Schlosser, I. J. 1988. Predation rates and the behavioral response of adult brassy minnows, Hybognathus hankinsoni, to creek chub and smallmouth bass predators. Copeia 1988: 691-697.

Shepard, T. E., P.E. O'Neil, S.W. McGregor, M.F., and W.P. Henderson. 1999. Status surveys of the Crystal darter (Crystallaria asprella) and Freckled darter (Percina lenticula) in Alabama: Summary of results, 1996-99. Geological Survey of Alabama. Tuscaloosa.

Simon, T. P., E. J. Tyberghein, K. J. Scheidegger, and C. E. Johnston. 1992. Descriptions of protolarvae of the sand darters (Percidae: Ammocrypta and Crystallaria) with comments on systematic relationships. Ichthyol. Explor. Freshwaters 3: 347-358.

Simons, A. 1991. Phylogenetic relationships of the crystal darter, Crystallaria asprella (Teleostei: Percidae). Copeia 1991: 4927-936.

Smart, H. J., and J. H. Gee. 1979. Coexistence and resource partitioning in two species of darters (Percidae), Etheostoma nigrum and Percina maculata. Can. J. Zool. 15: 2061-2071.

Smith, R. K. and K. D. Fausch. 1997. Thermal tolerances and vegetation preference of Arkansas darter and johnny darter from Colorado Plains streams. Trans. Amer. Fish. Soc. 126: 676686.

Stauffer, Jr., J. R., J.M. Boltz, K.A. Kellogg, and E.S. van Snik. 1996. Microhabitat partitioning in a diverse assemblage of darters in the Allegheny River system. Environ. Biol. Fish. 46: $37-44$.

Trautman, M. B. 1981. The fishes of Ohio. Ohio State University Press, Columbus.

Ultsch, G. R., H. Boschung, M. J. Ross. 1978. Metabolism, critical oxygen tension and habitat selection in darters (Etheostoma). Ecology 59: 99-107.

Welsh, S. A. and S. A. Perry. 1998. Habitat partitioning in a community of darters in the Elk River, West Virginia. Environ. Biol. Fish. 51: 411-419.

Werner, E. E., J. F. Gilliam, D. J. Hall, and G. G. Middlebach. 1983. An experimental test of the affects of predation risk on habitat use in fish. Ecology 64: 1540-1548.

White, M. W. and N. Aspinwall. 1984. Habitat partitioning among five species of darters (Percidae: Etheostoma). Pages 55-60 in D. G. Linquist and L. M. Page, editors. Environmental biology of darters. Dr W. Junk Pub. Co., The Hague, Netherlands. 
Whiteside, B. G. and R. M. McNatt. 1972. Fish species diversity in relation to stream order and physiochemical conditions in the Plum Creek drainage basin. Am. Midl. Nat. 88: 90-101.

Winemiller, K. O. 1992. Ecomorphology of freshwater fishes. Nat. Geog. Res. Explor. 8: 308327.

Winn, H. E. 1958. Comparative reproductive behavior and ecology of fourteen species of darters (Pisces: Percidae). Ecol. Monog. 28: 155-191.

Zorach, T. and E. C. Raney. 1967. Systematics of the Percid fish, Etheostoma maculatum

Kirtland, and related species of the subgenus Nothonotus. Amer. Mid. Nat. 77: 296-322. 


\section{Chapter 2:}

Distribution and habitat of Elk River crystal darters (Crystallaria asprella) 


\section{Introduction}

In the late 1800 s and early 1900 s, the crystal darter, Crystallaria asprella, was distributed widely within the Mississippi River drainage from Mississippi west to southeastern Oklahoma, north to southern Minnesota and southeast to Ohio; and in Gulf Coast drainages from the western panhandle of Florida to Mississippi (Page 1980, Keuhne and Barbour 1983, Grandmaison et al. 2003). The crystal darter's distribution decreased dramatically during the last century (Hatch 1997, Etnier and Starnes 1993). Stable populations occur in Alabama, Louisiana and Arkansas (George et al. 1996, Shepard et al. 1999, Hatch 1997) while populations in Minnesota, Wisconsin, Iowa, Indiana, and Oklahoma are restricted (Becker 1983, Taylor et al. 1993, Hatch 1997, Bowler 2001, Grandmaison et al. 2003). Populations within Ohio, Illinois, Kentucky and Tennessee are considered extirpated (Hatch 1997). Population declines of crystal darters are likely linked to losses of large river habitat. While there are few documented observations of crystal darter habitat use, many researchers generalize crystal darter habitat as areas of clean sand and gravel, and moderate to strong currents within the lower reaches of medium to large rivers (Table 1).

The crystal darter population in the Ohio River drainage is currently restricted to the Elk River of the lower Kanawha River system, West Virginia (Grandmaison et al. 2003). Wood and Raley (2000) and Morrison et al. (2004) reported that the crystal darter population in the Elk River, WV, is genetically distinct from populations in the Saline River, AR; Zumbro River, MN; Cahaba River, AL; and Pearl River, MS. Based on genetic results of Wood and Raley (2000), Warren et al. (2000) recognized the Elk River population as a distinct taxon (Crystallaria asprella spp., the Elk River crystal darter). 
The Elk River crystal darter was first collected in 1980, $1.6 \mathrm{rkm}$ below Mink Shoals in Kanawha County (Cincotta and Hoeft 1987). Seven crystal darters were subsequently collected from 1991 to 1999, including collections at Mink Shoals in August 1993 (1 individual) and near Clendenin, WV, in July 1991 (2 individuals), August 1993 (1 individual), September 1995 (2 individuals) and August 1999 (1 individual). All collections of Elk River crystal darters have occurred near Mink Shoals and Clendenin; Mink Shoals is $7.4 \mathrm{~km}$ from the mouth of Elk River, and Clendenin is $28.9 \mathrm{~km}$ upstream of Mink Shoals (Figure 1). Elk River crystal darters were collected from six of a total of 37 fish surveys on the lower $51 \mathrm{~km}$ of Elk River (King Shoals to the mouth) from 1936 through 2001 (Figure 1; Table 2).

Several scientists have recommended protection for the Elk River crystal darter (Wood and Raley 2000, Morrison et al. 2004, Boschung and Mayden 2004). Given few observations, however, little is known about distribution, population size, or habitat use of Elk River crystal darters. Any additional ecological information of Elk River crystal darters will aid management and protection of this rare species. Therefore, primary study objectives were to 1) determine the distribution of the crystal darter in the Elk River, and 2) document general characteristics of habitat use of crystal darters and habitat availability in the lower Elk River. Additionally, I documented sampling efforts from previous Elk River collections based on data from published and unpublished literature.

\section{Methods}

Study Area

The Elk River originates in Pocahontas County, flows $290 \mathrm{~km}$ west through central West Virginia, drops 631 meters in elevation, and converges with the Kanawha River in Charleston, West Virginia. The lower 51 river kilometers (rkm) of Elk River (King Shoals, WV, to 
Charleston, WV) has a relatively low gradient and low sinuosity, whereas the $111 \mathrm{rkm}$ section from King Shoals upstream to the flood control dam at Sutton, WV, has a higher gradient and higher sinuosity. Study areas were riffle/pool transitions within the lower $51 \mathrm{rkm}$ of Elk River. Before this study, Bill Tolin (USFWS, unpublished data) identified 28 riffle/pool transition areas in the lower 51 rkm section (Figure 1; Table 3). Riffle/pool transition areas (typically about 100 $\mathrm{m}$ in length) follow a habitat sequence of shallow, high velocity tails of riffles, moderate depth and velocity runs, and deep, slow velocity heads of pools. The substrate transition within this habitat sequence ranges generally from gravel/cobble/boulder in riffles to sand/gravel/cobble in runs and sand in pools.

\section{Data Collections}

During 2002 through 2004, I sampled fishes and collected qualitative and quantitative habitat data from riffle/pool transition habitats within the lower Elk River. Fish sampling gear included backpack electrofisher (Smith-Root model 12-B), electrofishing boat, seine (3.1 m width $x 1.2 \mathrm{~m}$ depth, and $0.32 \mathrm{~cm}$ mesh), and bag seines ( 4.6 or $6.1 \mathrm{~m}$ width and $1.8 \mathrm{~m}$ depth with a $1.2 \times 1.2 \times 1.2 \mathrm{~m}$ bag). Mesh size of bag seines was $0.64 \mathrm{~cm}$ in 2003 and $0.48 \mathrm{~cm}$ in 2004. Qualitative habitat data were collected at all sampling sites. At 10 sites, we also quantified habitat availability in addition to sampling fishes with bag seine.

During mid- to late summer of 2003 and 2004, I sampled 10 riffle/pool transitions in the lower Elk River (Figure 1; site 11 was sampled in 2003 and 2004) with bag seines. Fishes were sampled by hauling the seine downstream (typically for 15 meters), moving slightly faster than the water velocity. Approximate sample areas of each haul were summed to estimate the total sample area per site. Seine hauls of shorter distance occurred in areas of large boulders or other obstacles (e.g. tires, $\operatorname{logs}$ ). Additional weights along the seine's lead line ensured contact with 
the river bottom. Sampling occurred just after dusk, from approximately 2000 until 2400 hours. In 2003, we also sampled with bag seine at two sites during daylight. Due to concerns of safety and sampling efficiency, I seined during low flows ( $<350 \mathrm{cfs}$ [ $9.9 \mathrm{cms}]$; USGS stream gauge at Queen Shoals). Also, I kicked or backpack electrofished into a 3.1 x $1.2 \mathrm{~m}$ seine in areas of some sites, where obstacles or extremely high velocities hindered use of bag seines.

Habitat availability was quantified at 10 of the 28 riffle/pool sites on the same day as fish sampling. Habitat availability data were collected from 30 and 50 randomly-selected $\mathrm{m}^{2}$ quadrats per site in 2003 and 2004, respectively. Water depth (cm), mean water velocity (60\%

of depth, $\left.\mathrm{cm} \mathrm{sec}^{-1}\right)$, bottom water velocity $\left(2 \mathrm{~cm}\right.$ above substrate, $\left.\mathrm{cm} \mathrm{sec}{ }^{-1}\right)$, percent substrate composition (sand, gravel, cobble or boulder) and percent of embedded substrates were measured at each random location. Water velocity was measured with a flow meter (MarshMcBirney Flowmate, model 2000).

\section{Data Analysis}

Site comparisons of habitat availability were examined with principal components analysis (PCA; McGarigal et al. 2000) and descriptive univariate statistics (means and standard errors). Before PCA, continuous habitat variables (depth, bottom velocity, and mean velocity) and percent variables of substrate composition were normalized with $\log (+1)$ and arcsin transformations, respectively. Two PCAs were conducted; one PCA included velocity, depth, and substrate data, whereas another included only data on substrate types. Separate plots of PC1 x PC2 were depicted for each PCA. For each PC1 x PC2 plot, we used multivariate analysis of variance (MANOVA) to determine if clusters of site groups were significantly $(\mathrm{P}<0.05)$ different. An ANOVA and Tukey-Kramer test were used to determine differences along each 
PC axis, if clusters were significantly different along one axis independent of the second axis. All statistical tests were conducted with SAS software.

\section{Results}

During 2002 through 2004, I sampled on 20 occasions on the lower Elk River (Figure 1, Table 2), and quantified habitat availability at 10 sites (including sites of recent and previous crystal darter collections). Sampling with seines was restricted to warmer water temperatures of late summer and early fall during relatively low flows (Figures 2 and 3; Table 2). High flows prevented sampling until late August in 2003 (Figure 3). In 2004, sampling began in early July and continued through August (Table 2) until high water again hindered sampling (Figure 3). A bag seine produced two crystal darters at one site on August 29, 2003 (Site 11, Clendenin, WV, Table 4). No other crystal darters were collected or observed in 2003 or 2004, despite multiple efforts with bag seines, seines, electrofishing boat and backpack electrofishing. I also documented a total of 37 previous sampling efforts through a synthesis of fish collections on the lower Elk River (Table 2).

The two crystal darters were collected at site 11 (Clendenin, WV) near a sand bar off the toe of an island in approximately 0.5 to 0.75 meters of water over a mosaic of sand, large gravel, and cobble substrate. Mean water velocity within the general area of capture ranged from 10 to $45 \mathrm{~cm} / \mathrm{s}$. Based on measurements from randomly-selected quadrats at site 11 in 2003, depth ranged from 0.36 to $1.19 \mathrm{~m}$ and mean velocity (measured at 0.6 of depths) averaged $26.2 \mathrm{~cm} / \mathrm{sec}$. Mean values of substrate data were $31.6 \%$ gravel $(\mathrm{SE}=4.42), 25.8 \%$ cobble $(\mathrm{SE}=4.17)$ and $27.6 \%$ sand $(\mathrm{SE}=4.52)$ and percent embeddedness was $14.4(\mathrm{SE}=3.51$, Table 5). From a repeat sampling of Site 11 in 2004 (with no crystal darters collected), substrate composition 
consisted of a larger proportion of sand $(42.2, \mathrm{SE}=4.34)$ and a greater proportion of embedded substrate $(26.8, \mathrm{SE}=2.84)$ than in 2003 (Table 5).

In general, habitat availability data for most sites were consistent with crystal darter / habitat associations reported in the literature (Table 1) with relatively high percentages of sand (> 20\%) and gravel (> 20\%), and areas of moderate to strong velocities (mean velocity $>20 \mathrm{~cm}$ $\sec ^{-1}$; Table 5). Based on PCAs of the two datasets (all data and substrate data only), habitat availability was similar among sites, and confidence ellipses of site clusters of principal component scores overlapped among sites (Figure 4). The variation along PC1, influenced primarily by sand, gravel, and cobble, was intermediate for the Mink Shoals sites (27 and 28) and a Clendenin site (10) relative to that of other sites. Although 95\% confidence ellipses overlapped for all sites (Figure 4), some significant differences occurred among sites (MANOVAs, $\mathrm{F}_{(18,978)}=9.32, \mathrm{P}<0.05$ and $\mathrm{F}_{(18,978)}=7.76, \mathrm{P}<0.05$, respectively). For the analysis of substrate data, a Tukey-Kramer test indicated that the principal component cluster of site 11 along PC1 was significantly $(\mathrm{P}<0.05)$ less than those of sites 21,27 , and 10 . Also, along PC1, site 10 significantly exceeded that of sites 24 and 25 (Tukey-Kramer, $\mathrm{P}<0.05$ ).

In 2004, I quantified habitat availability at the three sites of previous crystal darter collections, and compared these habitat data to those from the 2003 collection at site 11 . At site 10 (at Clendenin water treatment plant), where crystal darters were collected in 1991, 1993, 1995 and 1999 (Table 2), the substrate in 2004 had a greater proportion of boulder $(16.0, \mathrm{SE}=2.61)$ and cobble (38.7, $\mathrm{SE}=2.44)$; and less sand $(15.6, \mathrm{SE}=2.05)$ than site 11 in 2003 (Table 5). At site 27, where crystal darters were collected in 1993 (Table 2), substrate also had a higher proportion of cobble $(45.9, \mathrm{SE}=3.14)$ and a lower proportion of sand $(17.2, \mathrm{SE}=2.41)$ than site 
11 in 2003 (Table 5). The percent of embedded substrates was also greater at sites 10 (36.9, SE $=2.16)$ and $27(38.0, \mathrm{SE}=2.22)$ than it was at site 11 in 2003 (Table 5).

On average, $34 \%$ of the area of bag seine sites were sampled in 2003 and 2004 (Table 4). At site 27 , only $11.5 \%$ of the area was sampled with bag seine due to physical obstacles and shallow water. Sampling effort at site 27, and several others, was supplemented with kickseining and backpack shocking. In general, habitat availability data for most sites were consistent with crystal darter / habitat associations reported in the literature (Table 1) with relatively high percentages of sand (> 20\%) and gravel (> 20\%), and areas of moderate to strong velocities (mean velocity $>20 \mathrm{~cm} \mathrm{sec}^{-1}$; Table 5).

A compilation of 57 historic and recent sampling events in the lower Elk River indicated little sampling effort until the 1970s. The only pre-1970 collections occurred in 1936 (Addair 1944; J. Addair, unpublished field notes); 13 collections occurred between 1970 and 1990; and (including recent data) 41 collections have occurred between 1990 and 2004 (Table 2).

\section{Discussion}

Collection of Elk River crystal darters in 1980, 1991, 1993, 1995, 1999, and 2003 supports population persistence in the lower Elk River, West Virginia. Given a life expectancy of 2 - 4 years (George et al 1996, Page 1983, Lutterbie 1979) and the 24-year time series (19802003) of observations, at least some Elk River crystal darters have spawned successfully over a relatively long time period. Currently, based on survey data, the distribution of crystal darters within the lower Elk River is limited to two areas (Mink Shoals and Clendenin). Quantitative and qualitative examination of habitat availability supports adequate habitat (based on velocity and benthic substrates; Table 1) for crystal darters at the 28 riffle/pool transitions with the lower 
$51 \mathrm{rkm}$. Population size of the Elk River crystal darter is unknown, but the number of individuals is likely small given low catch per effort from our recent data and previous data.

The rareness of the Elk River crystal darter and its "species of concern" designation (WVDNR 2003) are supported by the low catch per effort from a total of 57 fish surveys on the lower 51 rkm of Elk River from 1936 through 2004 (Table 2; Figure 1). The earliest recorded fish collections on the lower $51 \mathrm{rkm}$ of the Elk River occurred in 1936 (Addair 1944; J. Addair, unpublished field notes); however, most collections have occurred between 1971 and 2004. Although most efforts before this study did not target crystal darters, the low number of crystal darter observations from multiple gear types (seines, bag seines, boat elctrofishing and backpack electrofishing) supports a small population.

The recent survey efforts (2002-2004), during which only two crystal darters were collected from a total of 20 samples, further supports rareness of this species. Habitat data for these two specimens are consistent with previous information, i.e. moderate velocities over sand and gravel/cobble substrates. In addition to the 2003 observation, other collections of Elk River crystal darters were in areas of sand and gravel/cobble substrates (D. Cincotta, pers. comm.; S. Welsh, pers. comm.). Considerable effort (often hours of collecting within a relatively small area of stream) in some of the previous samples of Elk River crystal darters may have influenced habitat information. In 2003, the two individuals were collected during the first and third seine hauls; hence, the location (and associated habitat use information) of these individuals was unlikely influenced by the collectors.

Many records report small numbers of crystal darters per sampling site (Grandmaison et al. 2003). Gear avoidance may be one reason for low collection numbers. Crystal darters are 
reclusive in aquaria (Katula 2000), and may avoid sampling nets. However, others have successfully used bag seines to collect crystal darters (Hatch 1997, Shepard et al. 1999, Katula 2000). My bag seines were effective for many small benthic species, including eastern sand darters (Ammocrypta pellucida), a close-relative of Crystallaria. However, larger benthic fishes, such as adult suckers (Moxostoma), sauger (Sander canadensis), channel catfish (Ictalurus punctatus), and flathead catfish (Pylodictis olivaris) were rarely collected, despite a relatively high abundance within the lower Elk River. In addition to gear avoidance, sampling location may have influenced my catch rates. I sampled areas up to $1.5 \mathrm{~m}$ depths; hence, inference is not transferable to deeper waters. I did not use SCUBA for deepwater sampling because of turbidity and low sight distance.

The presence of moderate currents over cobble/gravel/sand substrates at sites near Clendenin and Mink Shoals (sites of previous collections of Elk River crystal darters) are consistent with the literature on crystal darter habitat (Table 1). These habitat characteristics in the lower Elk River, however, are not restricted to sites near Clendenin and Mink Shoals, but rather occur at all 28 riffle/pool transitions within the lower 51 rkm of the Elk River. My quantitative (10 sites including Clendenin and Mink Shoals) and qualitative (additional 18 sites) habitat data support adequate crystal darter habitat (based on substrate and velocity) at all 28 riffle/pool sites. Although sites exist with adequate habitat, the total length of river of these 28 riffle/pool sites is approximately 2800 meters, a relatively small amount (approximately $5.5 \%$ ) of the 51,000 m (51 rkm) of the lower Elk River (King Shoals to the mouth). Crystal darters, however, may use these riffle/pool habitats primarily during night and may occupy deeper pool habitats during the day. 
The site of crystal darter collection in 2003 (site 10, Clendenin, WV) had higher amounts of sand and less embedded substrate than sites 11 and 27 where crystal darters were collected in previous years. However, drastic year-to-year changes in amounts of sand and embedded substrates have been observed at the Clendenin site (site 10) over the last 15 years (D. Cincotta, pers. comm.; S. Welsh, pers. comm.); consequently, habitat characteristics at Clendenin (site 10) or Mink Shoals (site 27) in 2004 may not be comparable to prior conditions in years of crystal darter observations.

Given the importance of clean sand and gravel to crystal darter habitat, population persistence of Elk River crystal darters will likely be linked to sedimentation from land use. Although sedimentation is a natural process, land use practices within the Elk River watershed, such as logging, coal mining and oil and gas extraction, contribute to excessive and unnatural sedimentation (WVDEP 1997). In addition to environmental perturbation, small populations, such as the populations of the Elk River crystal darter near Clendenin and near Mink Shoals, are susceptible to extirpation from demographic stochasticity and catastrophic events (Lande 1988). Given uncertainties of population status, additional monitoring of the Elk River crystal darter is needed (Warren et al. 2000, Grandmaison et al. 2003). Given that adequate habitat exists in the lower Elk River, future efforts should consider captive propagation and supplemental stocking as a strategy for conservation of Elk River crystal darters.

\section{Literature Cited}

Addair, J. 1944. The fishes of the Kanawha River system in West Virginia and some factors which influence their distribution. Dissertation, Ohio State University, Columbus.

Becker, G. C. 1983. Fishes of Wisconsin. The Univ. of Wisconsin Press, Madison. 
Boschung, H. T., Jr. and R. L. Mayden. 2004. Fishes of Alabama. Smithsonian Books, Washington, D.C.

Bowler, M. C. 2001. Recent observations of the distribution and status of bluntnose darters and crystal darters in Iowa. J. Iowa Acad. Sci. 108: 15-18.

Cincotta, D. A. and M. E. Hoeft. 1987. Rediscovery of the crystal darter, Ammocrypta asprella, in the Ohio River Basin. Brimleyana 13: 133-136.

Etnier, D. A. and W.C. Starnes. 1993. The fishes of Tennessee. The Univ. of Tennessee Press, Knoxville.

Grandmaison, D., J. Mayasich, and D. Etnier. 2003. Crystal darter status assessment report. U. S. Fish and Wildlife Service. Technical Report \# NRRI/TR-2003/19 $<$ http://midwest.fws.gov/endangered/fishes/crda-sa.pdf> (18 August 2004)

George, S. G., W. T. Slack, and N. H. Douglas. 1996. Demography, habitat, reproduction and sexual dimorphism of the Crystal darter, Crystallaria asprella (Jordan), from southcentral Arkansas. Copeia 1996: 68-78.

Hatch, J. T. 1997. Resource utilization and life history of the Crystal darter, Crystallaria asprella (Jordan), in the Lower Mississippi River, Minnesota. Minnesota Natural Heritage and Nongame Wildlife Research Program, St Paul.

Jordan, D. S. 1878. A catalogue of fishes of Illinois. Ill. Nat. Hist. Surv. Bull. 2: 37-70.

Katula, R. 2000. Crystal clear: Observations on the Crystal darter (Crystallaria asprella). Freshwater and Marine Aquariums 3: 154.

Keuhne, R. A. and R. W. Barbour. 1983. The American darters. Univ. of Kentucky Press, Lexington.

Lande, R. 1988. Genetics and demography in biological conservation. Science 241: 1455-1461.

Lutterbie, G. W. 1979. Reproduction and age and growth in Wisconsin darters. Reports on the fauna and flora of Wisconsin 15: 1-44.

Lutterbie, G. W. 1976. The darters (Pisces:Percidae:Etheostomatinae) of Wisconsin. Dissertation, Univ. of Wisconsin, Stevens Point.

McGarigal, K., S. Cushman, S. Stafford. 2000. Multivariate statistics for wildlife and ecology research. Springer-Verlag New York, NY.

Miller, R. J. and H.W. Robison. 1973. The fishes of Oklahoma. Oklahoma State Univ. Press, Stillwater. 
Morrison, C. L., D. P. Lemarie, R. M. Wood, and T. L. King. 2004. Phylogeographic analyses suggest multiple lineages of Crystallaria asprella (Percidae: Etheostominae). Con. Gen. In Press.

Page, L. M. 1980. Ammocrypta asprella (Jordan) Crystal darter. Page 615. In: D. S. Lee, C. R. Gilbert, C. H. Hocutt, R. E. Jenkins, D. E. McAllister, J. R. Stauffer, Jr. editors, Atlas of North American freshwater fishes. N.C. State Mus. Nat. Hist., Raleigh.

Page, L. M. 1983. Handbook of darters. TFH Publications, Neptune City, NJ. 271 pp.

Pflieger, W. L. 1997. The fishes of Missouri. Missouri Dept. of Conservation, Jefferson City.

Robison, H. W. and T.M. Buchanan. 1988. Fishes of Arkansas. The Univ. of Arkansas Press, Fayetteville.

Ross, S. T. 2001. Inland fishes of Mississippi. Univ. Press of Mississippi, Jackson.

Shepard, T. E., P.E. O’Neil, S.W. McGregor, M.F., and W.P. Henderson. 1999. Status surveys of the Crystal darter (Crystallaria asprella) and Freckled darter (Percina lenticula) in Alabama: Summary of results, 1996-99. Geological Survey of Alabama. Tuscaloosa.

Simon, T. P., E. J. Tyberghein, K. J. Scheidegger, and C. E. Johnston. 1992. Descriptions of protolarvae of the sand darters (Percidae: Ammocrypta and Crystallaria) with comments on systematic relationships. Ichthyol. Explor. Freshwaters 3(4): 347-358.

Smith-Vaniz, W. F. 1968. Freshwater Fishes of Alabama. Paragon Press, Montgomery, AL.

Taylor, C.M., M. Pyron, and M.R. Winston. 1993. Zoogeographic implications for the first record of Crystallaria asprella (Percidae) from the Kiamichi River drainage, and for the occurrence of Notropis boops (Cyprinidae) and Luxilus chrysocephalus (Cyprinidae) in the Wichita Mountains, Oklahoma. The Southwestern Naturalist 38: 302-303.

Trautman, M. B. 1981. The fishes of Ohio. Ohio State University Press, Columbus.

Warren, M. L. and eleven others. 2000. Diversity, distribution and conservation status of the native freshwater fishes of the southern United States. Fisheries 25 (10): 7-31.

West Virginia Department of Environmental Protection (WVDEP). Division of Water Resources. Water Assessment Program. 1997. An Ecological Assessment of the Elk River Watershed. <http://www.wvdep.org/Docs/474_EAoftheElkRvrWatershed.pdf> (12 October 2004)

West Virginia Division of Natural Resources (WVDNR). Wildlife Diversity Program. 2003. Rare, Threatened and Endangered Species in West Virginia. <http://www.wvdnr.gov/Wildlife/RareSpecList.shtm> (12 October 2004) 
Wood, R., and M. Raley. 2000. Cytochrome b sequence variation in the crystal darter, Crystallaria asprella (Actinopterygii: Percidae). Copeia 2000: 20-26 
Tables and Figures 
Table 1. Summary of published descriptions of crystal darter habitat including current velocity and substrate composition.

\begin{tabular}{|c|c|}
\hline State/Region & Current Velocity \\
\hline Alabama & moderate to swift runs \\
\hline Alabama & areas of higher current velocity \\
\hline Alabama & strong current \\
\hline Alabama & $\begin{array}{l}\text { moderate to swift side channel } \\
\text { riffle for spawning }\end{array}$ \\
\hline Arkansas & strong current \\
\hline Arkansas & $46-90 \mathrm{~cm} / \mathrm{s}$ \\
\hline entire range & strong current \\
\hline entire range & steady current \\
\hline \multicolumn{2}{|l|}{ Illinois } \\
\hline \multicolumn{2}{|l|}{ Iowa } \\
\hline Minnesota & $\begin{array}{c}\text { moderate to strong currents; } \\
60.8-37.6 \mathrm{~cm} / \mathrm{sec}\end{array}$ \\
\hline \multicolumn{2}{|l|}{ Minnesota } \\
\hline Mississippi & $66 \mathrm{~cm} / \mathrm{s}$ (range $25-100 \mathrm{~cm} / \mathrm{s}$ ) \\
\hline $\begin{array}{l}\text { Missouri } \\
\text { Ohio }\end{array}$ & slight current \\
\hline Oklahoma & \\
\hline Oklahoma & \\
\hline Oklahoma & \\
\hline Oklahoma & \\
\hline
\end{tabular}

Bottom Substrate

sand and gravel mix; Cahaba River

stable sand bars; cobble, gravel, and sand; Alabama River

gravel or sand bottom

spawn over course sand and gravel; Tallapoosa River

sand or fine gravel

primarily gravel, with some small cobble and patches of

$$
\text { sand }
$$

clean sand and gravel

clean sand or gravel

sandy stream (Little Wabash River); small rocky tributary of the Mississippi River

sand; Pool 11 Mississippi River

coarse sand and gravel with $30-40 \%$ embedded cobble and boulder; main channel Mississippi River

driftwood and debris caught in shifting sand; Zumbrow

$$
\text { River }
$$

clean sand and large gravel

sand or small gravel

sandy riffles, bars, and pool bottoms;

sand or fine gravel

sand/gravel mix at pool/riffle interface; Kiamichi River sandy backwater

riffle with gravel substrate
Citation

Shepard et al. 1999

Shepard et al. 1999

Smith-Vaniz 1968;

Boschung and Mayden 2004

Simon et al. 1992

Robison and Buchanan 1988

George et al. 1996

Page 1983

Kuehne and Barbour 1983

Jordan 1876

Bowler 2001

Hatch 1997

J. Underhill, pers. comm. As cited in Becker (1983) Ross 2001

Pflieger 1997

Trautman 1981

Miller and Robison 1973

Taylor et al. 1993

Taylor et al. 1993

Taylor et al. 1993 
Table 1. Continued.

$\begin{array}{cccc}\text { State/Region } & \text { Current Velocity } & \text { Bottom Substrate } \\ \text { Tennessee } & \text { swifter portions of shoal areas } & \text { clean sand and gravel } & \text { Citation } \\ \text { West Virginia } & \text { moderate to strong currents } & \text { adjacent to submerged log in sandy run; 25\% rubble, 50\% } & \text { Cincotta and Hoeft 1987 } \\ \text { Wisconsin } & \text { moderate current } & \text { sandy riffles, bars, and pool bottoms } \\ \text { Wisconsin } & \text { gravelly bar; Mississippi River at Cassville } & \text { Becker 1983 } \\ \text { Wisconsin } & \text { moderately flowing } & \text { 10-25\% sand and } 90 \text { to } 75 \% \text { gravel; Chippewa River } & \text { Becker 1983 } \\ \text { Wisconsin } & & \text { extensive rock shelf; Wisconsin River }\end{array}$


Table 2. Summary of fish collections on the Elk River between King Shoals and Charleston, WV from 1936 to 2004. Crystal darter observations indicated with "Y" (yes).

\begin{tabular}{|c|c|c|c|c|c|c|}
\hline YR & M & $\mathrm{D}$ & $\begin{array}{l}\text { UTM } \\
\text { EW }\end{array}$ & $\begin{array}{l}\text { UTM } \\
\text { NS }\end{array}$ & $\begin{array}{l}\text { CRYSTAL } \\
\text { DARTER }\end{array}$ & LOCATION DESCRIPTION \\
\hline 1936 & 7 & 4 & 456069 & 4251240 & & 7 mi. above Clendenin, WV \\
\hline 1936 & 7 & 5 & 479132 & 4261873 & & $\begin{array}{l}\text { at mouth of Little Sandy Creek, } 15 \mathrm{mi} \text { above } \\
\text { Charleston, WV }\end{array}$ \\
\hline 1936 & 7 & 5 & 448767 & 4249434 & & 2.5 mi. above Charleston, WV \\
\hline 1971 & 10 & 20 & 475240 & 4257980 & & $\begin{array}{l}23.0 \text { mi. above mouth - pool under \& above Queen } \\
\text { Shoals bridge (HWY 1) }\end{array}$ \\
\hline 1973 & 9 & 6 & 472200 & 4259560 & & $23.5 \mathrm{mi}$. above mouth \\
\hline 1973 & 9 & 6 & 473980 & 4258600 & & 22.5 mi. above mouth \\
\hline 1973 & 9 & 6 & 473680 & 4258900 & & 22.0 mi. above mouth \\
\hline 1978 & 9 & 8 & 447220 & 4247320 & & $\begin{array}{l}3.0 \text { mi. above mouth - stream section adj. to I-79 } \\
\text { construction \& Kanawha Airport }\end{array}$ \\
\hline 1979 & 4 & 20 & 479160 & 4261860 & & 29.8 mi. above mouth - at mouth of King Shoals Run \\
\hline 1979 & 9 & 11 & 448940 & 4248700 & & 4.24 mi. above mouth \\
\hline 1980 & 11 & 13 & 448993 & 4249845 & $\mathrm{Y}$ & $\begin{array}{l}3.6 \mathrm{mi} \text {. above mouth to } 5.1 \mathrm{mi} \text {. above mouth adjacent } \\
\text { to Coonskin Park }\end{array}$ \\
\hline 1981 & 9 & 23 & 449559 & 4249982 & & $\begin{array}{l}\text { from Mink Shoals to Garnett School at Big Chimney, } \\
\text { WV near Coonskin Park }\end{array}$ \\
\hline 1982 & 11 & 16 & 465249 & 4257890 & & $\begin{array}{l}17.8 \text { mi. above mouth, at mouth of Jordan Cr. near } \\
\text { Falling Rock, WV }\end{array}$ \\
\hline 1983 & 2 & 22 & 475189 & 4257898 & & at mouth of Queen Shoals Cr. \\
\hline 1983 & 8 & 26 & 450720 & 4249400 & & Big Chimney, WV downstream to Mink Shoals \\
\hline 1986 & 6 & 2 & 465276 & 4257880 & & at mouth of Jordan Creek \\
\hline 1991 & 7 & 18 & 471076 & 4260078 & $\mathrm{Y}$ & at Clendenin water treatment plant \\
\hline 1993 & 8 & 4 & 471076 & 4260078 & $\mathrm{Y}$ & at Clendenin water treatment plant \\
\hline 1993 & 8 & 5 & 448783 & 4249360 & $\mathrm{Y}$ & at Mink Shoals \\
\hline 1995 & 6 & 27 & 475078 & 4257960 & & at Queen Shoals \\
\hline 1995 & 6 & 27 & 471076 & 4260078 & & at Clendenin water treatment plant \\
\hline 1995 & 8 & 5 & 471076 & 4260078 & & at Clendenin water treatment plant \\
\hline 1995 & 8 & 5 & 448783 & 4249360 & & at Mink Shoals \\
\hline 1995 & 8 & 13 & 448783 & 4249360 & & at Mink Shoals \\
\hline 1995 & 8 & 13 & 471076 & 4260078 & & at Clendenin water treatment plant \\
\hline 1995 & 8 & 13 & 475078 & 4257960 & & at Queen Shoals \\
\hline 1995 & 9 & 20 & 471076 & 4260078 & $\mathrm{Y}$ & at Clendenin water treatment plant \\
\hline 1995 & 10 & 21 & 471076 & 4260078 & & at Clendenin water treatment plant \\
\hline 1995 & 10 & 21 & 448783 & 4249360 & & at Mink Shoals \\
\hline 1996 & 6 & 20 & 448783 & 4249360 & & at Mink Shoals \\
\hline 1996 & 7 & 14 & 446590 & 4246241 & & from mouth upstream to Mink Shoals \\
\hline
\end{tabular}


Table 2. Continued.

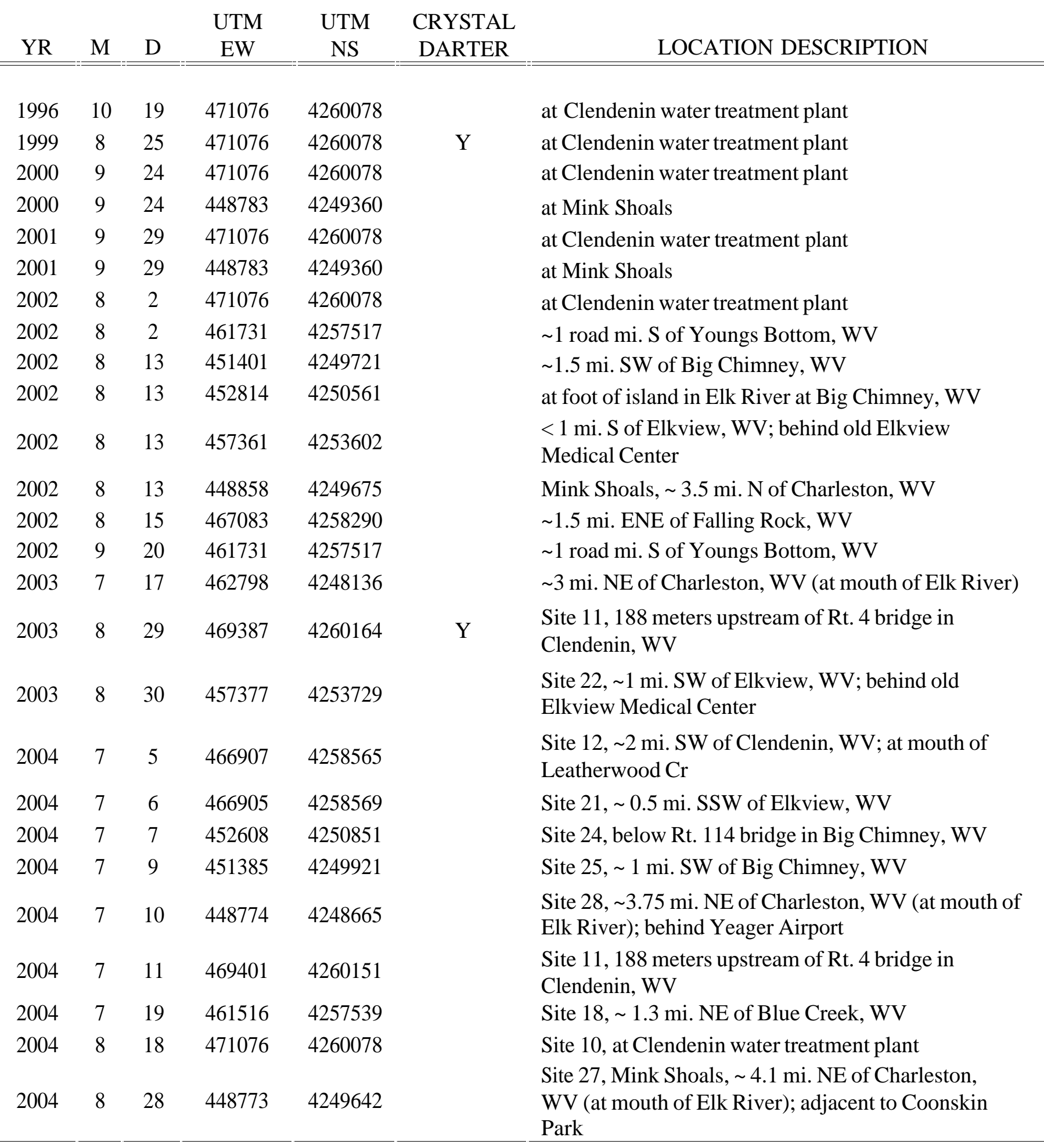


Table 3. Site locations of 28 riffle/pool transition areas on the lower $51 \mathrm{~km}$ of Elk River.

\begin{tabular}{|c|c|c|c|c|}
\hline SITE & UTM EW & UTM NS & Location description & $\begin{array}{l}\text { Distance from } \\
\text { mouth }(\mathrm{km})\end{array}$ \\
\hline 1 & 479040 & 4262080 & $3.2 \mathrm{~km} \mathrm{NW}$ of Procious, WV & 51 \\
\hline 2 & 478336 & 4261911 & $1 \mathrm{~km}$ NNE of Porter, WV & 50.2 \\
\hline 3 & 478350 & 4260947 & $1.8 \mathrm{~km}$ NNE of Porter, WV & 49.2 \\
\hline 4 & 478174 & 4260412 & $1.1 \mathrm{~km}$ NE of Porter WV & 48.6 \\
\hline 5 & 477336 & 4259286 & $0.4 \mathrm{~km} \mathrm{SW}$ of Porter, WV & 47.1 \\
\hline 6 & 474830 & 4258110 & Queen Shoals & 42 \\
\hline 7 & 473697 & 4259110 & $0.9 \mathrm{~km}$ NW of Queen Shoals, WV & 40.4 \\
\hline 8 & 472740 & 4259567 & 1.4 km SE of Queen Shoals, WV & 39.3 \\
\hline 9 & 472113 & 4259779 & $1.3 \mathrm{~km} \mathrm{SE}$ of Clendenin, WV & 38.6 \\
\hline 10 & 471079 & 4260299 & $\begin{array}{l}0.9 \mathrm{~km} \text { E of Clendenin, WV at Clendenin Water } \\
\text { Treatment Facility }\end{array}$ & 37.4 \\
\hline 11 & 469460 & 4260166 & Adjacent to Clendenin, WV upstream of Rt. 4 bridge & 35.7 \\
\hline 12 & 466989 & 4258504 & $\begin{array}{l}3.2 \mathrm{~km} \mathrm{SW} \text { of Clendenin, WV; at mouth of } \\
\text { Leatherwood } \mathrm{Cr}\end{array}$ & 32.7 \\
\hline 13 & 465285 & 4258054 & $0.2 \mathrm{~km}$ E of Falling Rock, WV; mouth of Jordan Creek & 30.9 \\
\hline 14 & 465088 & 4257801 & $\begin{array}{l}\text { Adjacent to Falling Rock, WV; mouth of Falling Rock } \\
\text { Creek }\end{array}$ & 30.6 \\
\hline 15 & 464574 & 4257167 & 0.4 km S of Falling Rock, WV & 29.8 \\
\hline 16 & 463504 & 4256850 & $0.3 \mathrm{~km}$ SE of Youngs Bottom, WV & 28.7 \\
\hline 17 & 463272 & 4256801 & $0.2 \mathrm{~km}$ SE of Youngs Bottom, WV; mouth of Sand Run & 28.5 \\
\hline 18 & 461794 & 4257639 & $2 \mathrm{~km}$ NE of Blue Creek, WV & 26.7 \\
\hline 19 & 459943 & 4255548 & $\begin{array}{l}0.2 \mathrm{~km} \mathrm{SW} \text { of Blue Creek, WV; adjacent to island } \\
\text { below mouth of Blue Creek }\end{array}$ & 23.8 \\
\hline 20 & 457887 & 4254767 & $\begin{array}{l}\text { Adjacent to town of Elkview, WV; mouth of Little } \\
\text { Sandy Creek }\end{array}$ & 21.5 \\
\hline 21 & 457394 & 4253887 & $0.5 \mathrm{~km} \mathrm{SW}$ of Elkview, WV & 20.3 \\
\hline 22 & 456937 & 4252120 & $0.7 \mathrm{~km} \mathrm{NW}$ of Pinch, WV & 18.4 \\
\hline 23 & 455987 & 4251416 & $1 \mathrm{~km} \mathrm{~W}$ of Pinch, WV & 16 \\
\hline 24 & 452805 & 4250895 & below Rt. 114 bridge in Big Chimney, WV & 14.3 \\
\hline 25 & 451453 & 4249966 & $0.2 \mathrm{~km}$ E of Creed, WV & 11 \\
\hline 26 & 449468 & 4250276 & Adjacent to Elk Hills, WV & 8.7 \\
\hline 27 & 448807 & 4249656 & $\begin{array}{l}\text { Mink Shoals, } 6.5 \mathrm{~km} \text { NE of Charleston, WV; adjacent } \\
\text { to Coonskin Park }\end{array}$ & 7.6 \\
\hline 28 & 448715 & 4248650 & $6 \mathrm{~km}$ NE of Charleston, WV; behind Yeager Airport & 6.5 \\
\hline
\end{tabular}


Table 4. Summary of bag seine sampling efforts by site. Sampling effort $(*)$ was supplemented by kickseining in riffles and near obstacles. Sampling effort (**) was supplemented by backpack shocking into a $3.1 \times 1.2 \mathrm{~m}$ seine in riffles and near obstacles.

\begin{tabular}{|c|c|c|c|c|c|c|}
\hline Site & Date & $\begin{array}{l}\text { Area of } \\
\text { sample } \\
\text { site } \\
\left(\mathrm{m}^{2}\right)\end{array}$ & $\begin{array}{c}\text { Approximate } \\
\% \text { area } \\
\text { sampled }\end{array}$ & $\begin{array}{c}\text { Number } \\
\text { of } \\
\text { Seine } \\
\text { hauls }\end{array}$ & $\begin{array}{c}\text { Crystal } \\
\text { darter } \\
\text { observations } \\
\text { Yes/no }\end{array}$ & $\begin{array}{c}\text { Time } \\
\text { of } \\
\text { sampling }\end{array}$ \\
\hline 11 & $8 / 29 / 2003$ & 13,724 & 10.0 & 15 & $\mathrm{~N}$ & Day \\
\hline 11 & 8/29/2003 & 13,724 & 11.0 & 17 & Y & Night \\
\hline 22 & $8 / 30 / 2003$ & 6000 & 23.0 & 15 & $\mathrm{~N}$ & Day \\
\hline 22 & $8 / 30 / 2003$ & 6000 & 26.0 & $17 *$ & $\mathrm{~N}$ & Night \\
\hline 12 & $7 / 5 / 2004$ & 4176 & 39.0 & 28 & $\mathrm{~N}$ & Night \\
\hline 21 & $7 / 6 / 2004$ & 4588 & 35.0 & 27 & $\mathrm{~N}$ & Night \\
\hline 24 & $7 / 7 / 2004$ & 1755 & 86.0 & 26 & $\mathrm{~N}$ & Night \\
\hline 25 & $7 / 9 / 2004$ & 2451 & 47.2 & $26^{*}$ & $\mathrm{~N}$ & Night \\
\hline 28 & 7/10/2004 & 2520 & 47.9 & 26 & $\mathrm{~N}$ & Night \\
\hline 11 & $7 / 11 / 2004$ & 4500 & 40.1 & $32 *$ & $\mathrm{~N}$ & Night \\
\hline 18 & $7 / 18 / 2004$ & 3496 & 32.8 & $26 * *$ & $\mathrm{~N}$ & Night \\
\hline 10 & $8 / 18 / 2004$ & 1863 & 32.1 & $17 *$ & $\mathrm{~N}$ & Night \\
\hline 27 & $8 / 28 / 2004$ & 2850 & 11.5 & $12 * *$ & $\mathrm{~N}$ & Night \\
\hline
\end{tabular}


Table 5. Average habitat values by site with standard error (SE) in italics. Velocity values of " $2 \mathrm{~cm}$ " and "mean" were measured at 2 $\mathrm{cm}$ above the substrate, and at 0.6 percent of depth, respectively.

Sampling sites (year in parentheses)

\begin{tabular}{|c|c|c|c|c|c|c|c|c|c|c|c|}
\hline Habitat type & $\begin{array}{c}10 \\
(2004)\end{array}$ & $\begin{array}{c}11 \\
(2004)\end{array}$ & $\begin{array}{c}11 \\
(2003)\end{array}$ & $\begin{array}{c}12 \\
(2004)\end{array}$ & $\begin{array}{c}18 \\
(2004)\end{array}$ & $\begin{array}{c}21 \\
(2004)\end{array}$ & $\begin{array}{c}22 \\
(2003)\end{array}$ & $\begin{array}{c}24 \\
(2004)\end{array}$ & $\begin{array}{c}25 \\
(2004)\end{array}$ & $\begin{array}{c}27 \\
(2004)\end{array}$ & $\begin{array}{c}28 \\
(2004)\end{array}$ \\
\hline$\%$ Sand & 15.6 & 42.2 & 27.6 & 29.4 & 17.0 & 16.0 & 37.5 & 51.6 & 29.1 & 17.2 & 23.3 \\
\hline$S E$ & 2.05 & 4.34 & 4.52 & 4.45 & 4.87 & 1.25 & 6.73 & 4.21 & 4.79 & 2.41 & 2.66 \\
\hline$\%$ Gravel & 27.8 & 31.4 & 31.6 & 23.2 & 31.3 & 37.0 & 24.7 & 17.5 & 21.0 & 26.1 & 24.5 \\
\hline$S E$ & 2.15 & 3.20 & 4.42 & 4.47 & 4.24 & 2.81 & 4.38 & 2.49 & 3.93 & 3.09 & 2.30 \\
\hline$\%$ Cobble & 38.7 & 23.6 & 25.8 & 31.6 & 34.2 & 40.8 & 27.9 & 28.8 & 28.9 & 45.9 & 40.1 \\
\hline$S E$ & 2.44 & 2.22 & 4.17 & 4.39 & 3.88 & 2.62 & 3.67 & 3.01 & 3.46 & 3.14 & 2.85 \\
\hline$\%$ Boulder & 16.0 & 2.0 & 3.5 & 13.9 & 15.2 & 5.3 & 9.8 & 2.2 & 15.0 & 9.0 & 11.9 \\
\hline$S E$ & 2.61 & 1.03 & 1.27 & 3.02 & 4.18 & 1.58 & 3.18 & 0.86 & 2.75 & 2.09 & 2.96 \\
\hline$\%$ Other & 1.5 & 0.6 & 11.3 & 2.0 & 2.3 & 0.0 & 0.2 & 0.0 & 5.8 & 1.4 & 0.0 \\
\hline$S E$ & 1.40 & 0.44 & 5.19 & 1.06 & 1.68 & 0.00 & 0.17 & 0.00 & 2.64 & 0.99 & 0.00 \\
\hline Embedded & 36.9 & 26.8 & 14.4 & 44.8 & 37.5 & 27.8 & 30.8 & 22.3 & 25.0 & 38.0 & 39.9 \\
\hline$S E$ & 2.16 & 2.84 & 3.51 & 3.94 & 3.88 & 2.37 & 4.68 & 2.59 & 3.08 & 2.22 & 2.90 \\
\hline Depth (cm) & 46.27 & 54.32 & 75.46 & 61.4 & 52.32 & 39.75 & 72.31 & 36.82 & 67.79 & 50.29 & 44.99 \\
\hline$S E$ & 2.95 & 1.11 & 3.18 & 3.9 & 4.08 & 1.34 & 4.32 & 2.58 & 3.72 & 3.96 & 3.12 \\
\hline $\begin{array}{r}2 \mathrm{~cm} \text { velocity } \\
(\mathrm{cm} / \mathrm{s})\end{array}$ & 18.56 & 10.16 & 11.26 & 7.54 & 10.64 & 12.82 & 14.49 & 9.79 & 5.67 & 14.14 & 7.58 \\
\hline$S E$ & 1.43 & 1.12 & 2.08 & 1.6 & 2.03 & 0.91 & 1.62 & 1.01 & 1.61 & 2.08 & 1.69 \\
\hline $\begin{array}{r}\text { Mean velocity } \\
(\mathrm{cm} / \mathrm{s})\end{array}$ & 41.69 & 24.55 & 26.22 & 18.47 & 24.58 & 29.52 & 31.37 & 21.24 & 16.89 & 29.1 & 23.52 \\
\hline$S E$ & 2.66 & 2.04 & 3.61 & 2.32 & 4.08 & 1.04 & 2.52 & 1.52 & 3.21 & 2.58 & 2.93 \\
\hline
\end{tabular}


Figure 1. Map of riffle/pool transition sites identified by Bill Tolin (USFWS, unpublished data) on the lower $51 \mathrm{rkm}$ of the Elk River from King Shoals to Charleston, West Virginia. Closed symbols designate locations sampled during this study.

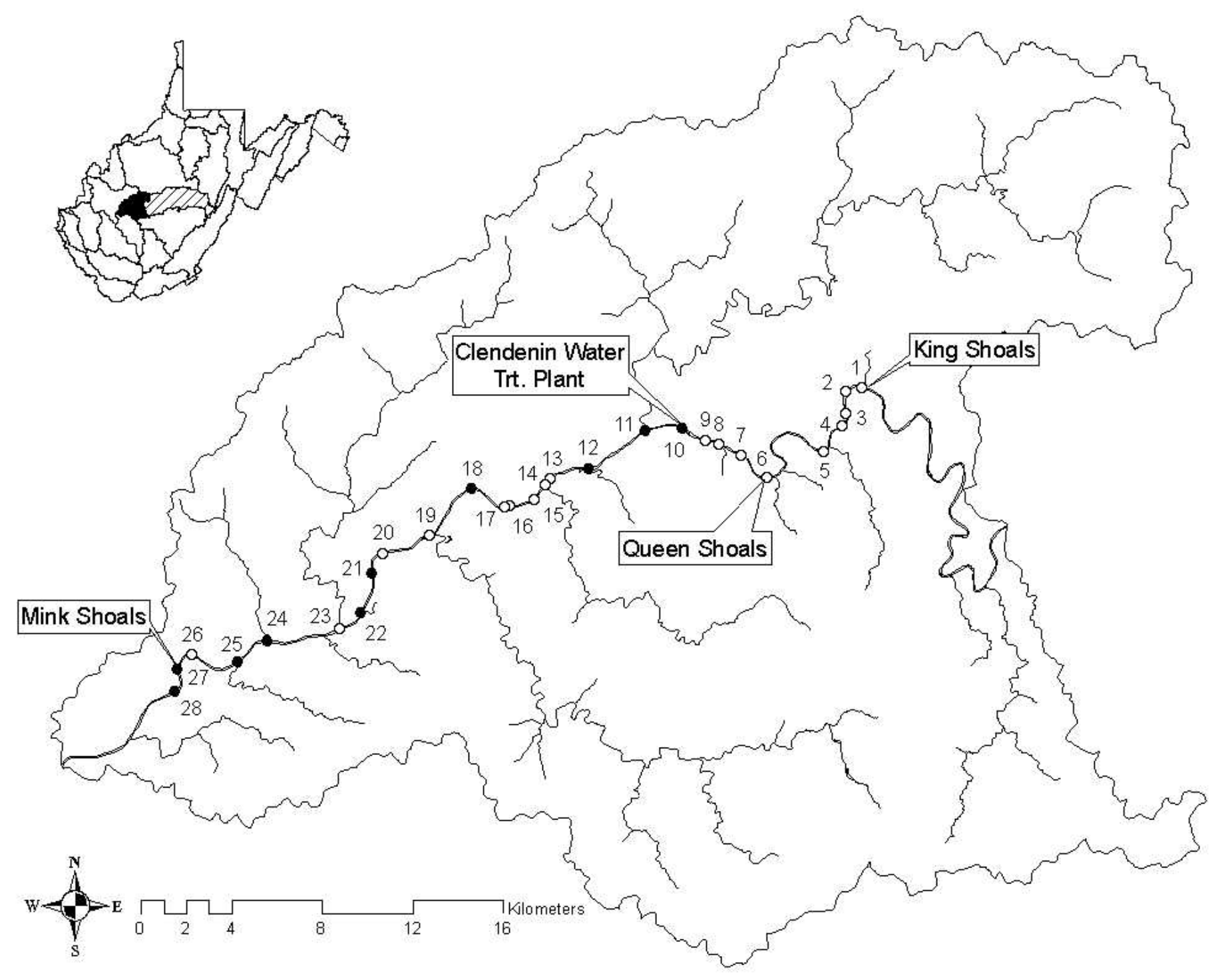


Figure 2. Daily water temperature $\left({ }^{\circ} \mathrm{C}\right)$ of the Elk River at Queen Shoals (13 September 2002 until 3 July 2004).

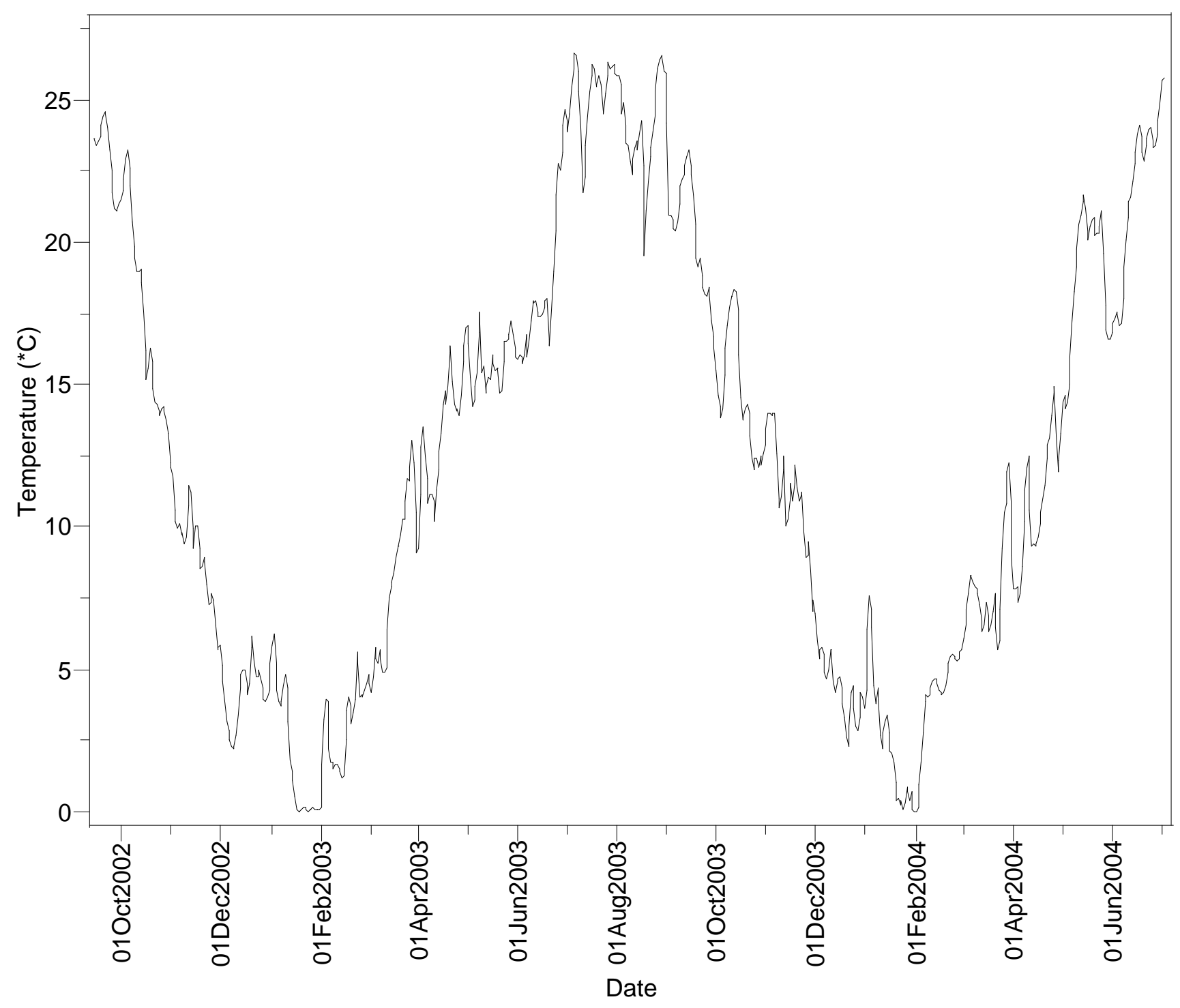


Figure 3. Mean daily discharge $\left(\mathrm{m}^{3} / \mathrm{s}\right)$ of the Elk River from the USGS gauging station at Queen Shoals (1 August 2002 to 31 August 2004).

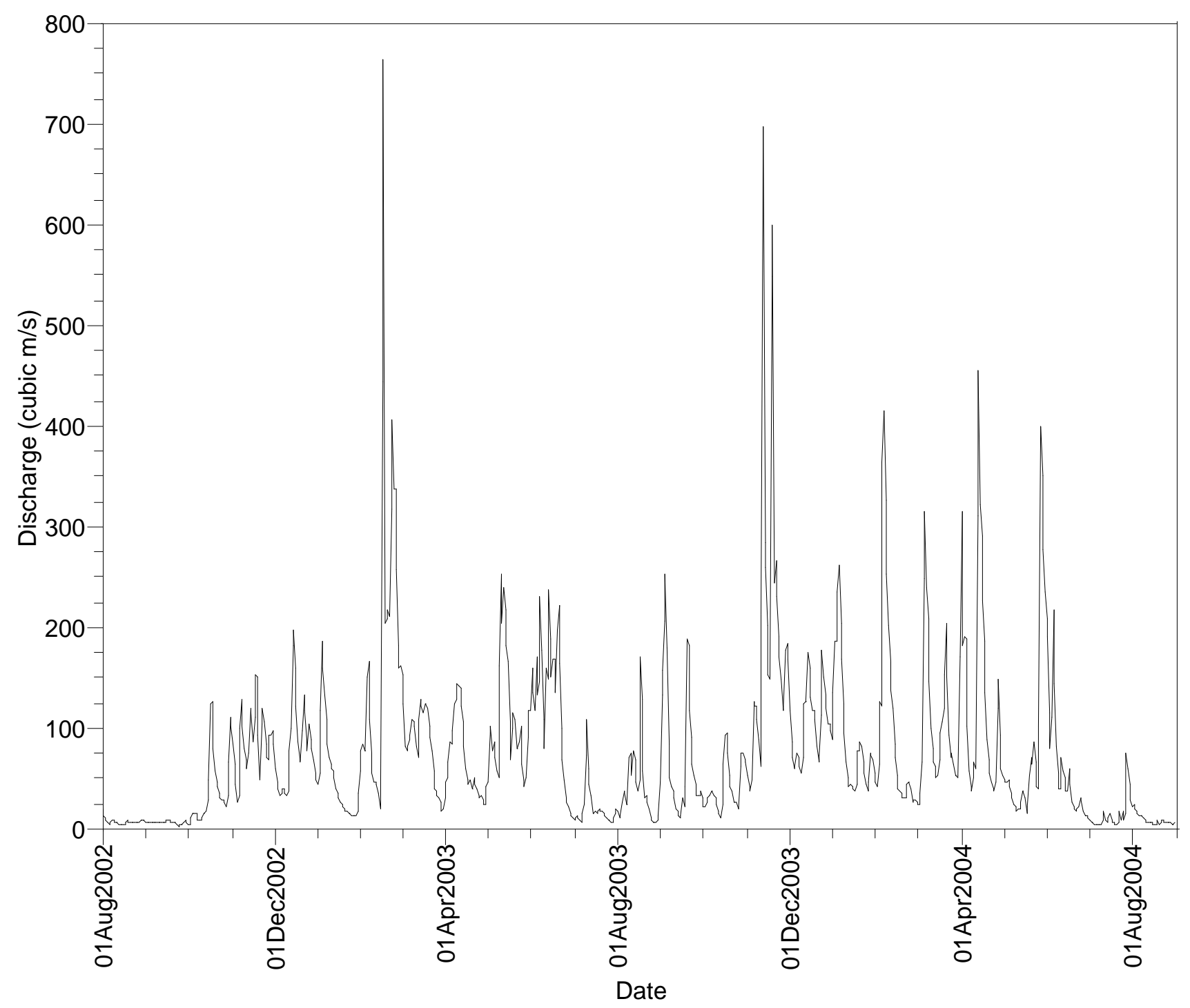


Figure 4. Habitat availability data of 10 sites on the lower Elk River depicted as confidence ellipses (95\%) of principal component clusters; (A) PCA of all habitat data (velocity, depth, and substrate percents) and (B) PCA of substrate only. Bold ellipses depict previous crystal darter collection sites near Clendenin (10 and 11) and Mink Shoals (27 and 28).
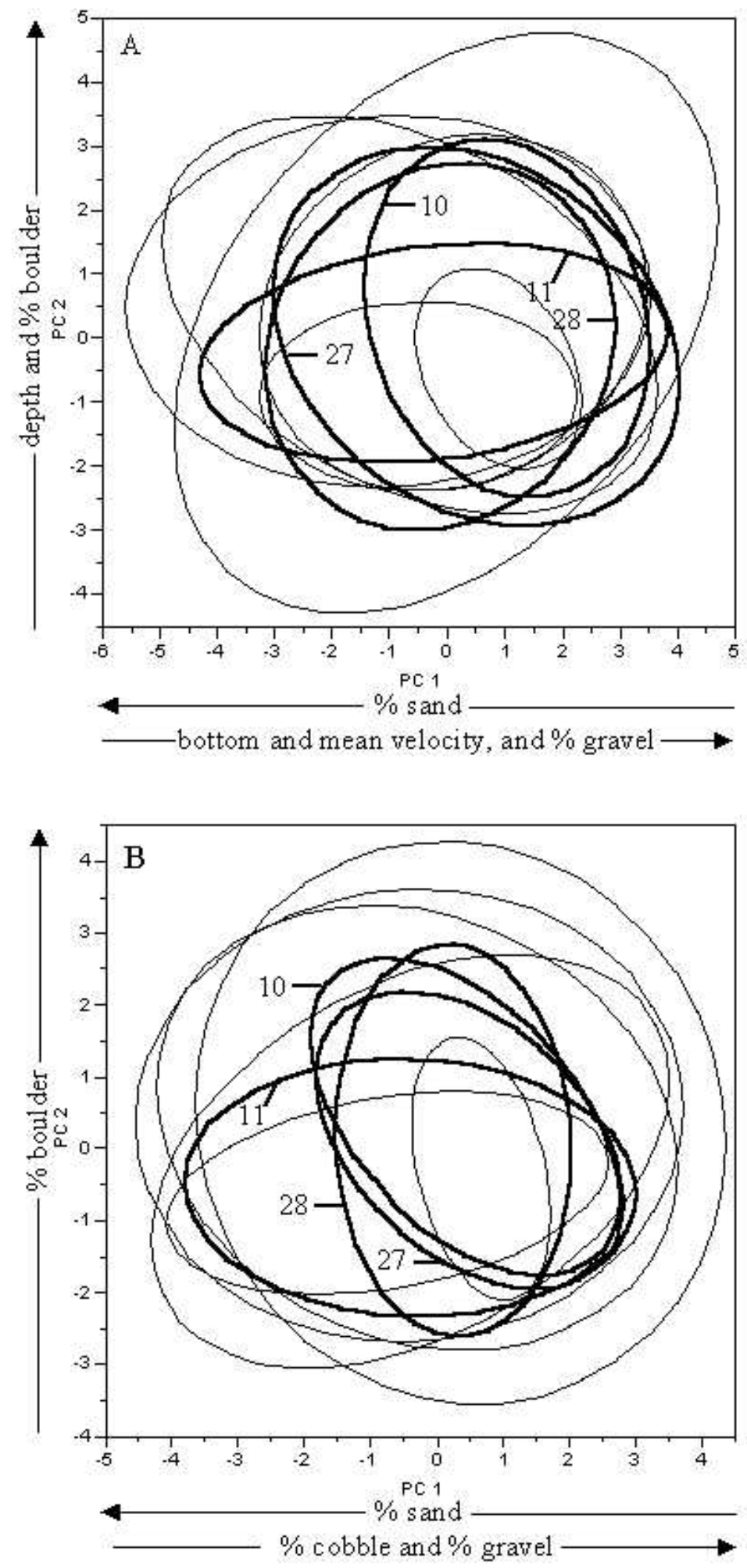


\section{Chapter 3:}

Habitat use of the Elk River spotted darter, Etheostoma maculatum*

* This chapter is formatted following the guidelines of the journal of Environmental Biology of Fishes. 
Synopsis

The spotted darter, Etheostoma maculatum, is distributed disjunctly within the Ohio River drainage. Researchers have generalized spotted darter habitat as large rocks and swift riffles. In West Virginia, spotted darters occur only within the middle section of Elk River system, but information on habitat use is lacking. With direct observation (snorkeling), we examined microhabitat use of spotted darters in riffle and run habitats at three sites in the Elk River. Contrary to habitat use data from other populations, spotted darters in the Elk River were observed primarily in run habitats near large rocks and within moderate velocities. The Elk River spotted darter, a habitat specialist, is highly vulnerable to habitat alterations, such as sedimentation and substrate embeddedness. Given a small geographic range, further ecological studies are needed for conservation and management of Elk River spotted darters. 


\section{Introduction}

Spotted darters, Etheostoma maculatum, are distributed disjunctly within the Ohio River drainage (Page \& Burr 1991). Population isolates of the spotted darter occur in the Allegheny River watershed, Pennsylvania and New York (Raney \& Lachner 1939, Stauffer et al. 1996), the Scioto River watershed, Ohio (Trautman 1981), the Blue River (Baker et al. 1985) and Wabash River watersheds (Etnier 1980), Indiana, and the Green River (Kessler \& Thorp 1993, Kessler 1994, Kessler et al. 1995) and North Fork Kentucky River watersheds (Burr \& Warren 1986), Kentucky. Range fragmentation of E. maculatum mirrors that of other regional species (such as Erimystax dissimilis, Etheostoma tippecanoe, Etheostoma camurum, and Percina evides) which is a geographic pattern attributed to recent degradation and fragmentation of habitat following post-Pleistocene dispersal (Simons 2004). Owing to small isolated populations, state agencies have listed spotted darters as threatened, endangered, or as "species of special concern." In West Virginia, spotted darters occur only in the lower Kanawha River system in middle portions of the Elk River (Cincotta et al. 1986, Stauffer et al. 1995), where populations are known from ten sites (Appendix 1). The spotted darter population from Elk River differs morphologically from populations of other drainages (Welsh et al. ${ }^{1}$ ).

Spotted darters use riffle habitats with relatively fast velocities and large substrate in the Allegheny (Raney \& Lachner 1939, Stauffer et al. 1996), Scioto (Trautman 1981) Green (Kessler \& Thorp 1993, Kessler et al. 1995) and Kentucky (Burr \& Warren 1986) river systems. Spotted darters are frequently observed under or near boulders or large cobbles (Raney

\footnotetext{
${ }^{1}$ Welsh, S.A., D.A. Cincotta, R.L. Raesly, \& R.M. Wood. 2002. Morphological variation among populations of the spotted darter (Etheostoma maculatum). From Program Book and Abstracts, Joint Meeting of Ichthyologists and Herpetologists, Kansas City, Missouri. 327 pp. Available from the internet URL

http://www.asih.org/meetings/2002/Abstracts.pdf
} 
\& Lachner 1939, Kessler \& Thorp 1993). Before this study, however, no information existed on habitat use of Elk River spotted darters. Therefore, our objective was to quantify microhabitat use of the spotted darter in the Elk River, West Virginia.

\section{Materials and methods}

\section{Study Site}

The Elk River, located in central West Virginia, flows west $290 \mathrm{~km}$ and drops 631 meters in elevation before entering the Kanawha River (Figure 1). The middle section of Elk River supports spotted darters, a section with relatively moderate gradients and high sinuosity (Appendix 1). In this study, we examined microhabitat use of Elk River spotted darters in riffle and run habitats at three sites adjacent to towns of Spread, Whetstone, and Ivydale. At Spread and Whetstone, run habitats were immediately upstream of the head of riffles, whereas at Ivydale, the run habitat paralleled the riffle habitat (separated by a narrow island). At each site, the size of the study area varied with available riffle or run habitat (Table 1).

\section{Habitat availability}

Random sampling was used to examine habitat availability of riffle and run habitats, where approximately 30 locations per site were selected randomly from a site grid of numbered 1 $\mathrm{m}^{2}$ cells. At each random location, we measured mean water velocity ( $60 \%$ of depth, $\left.\mathrm{cm} \mathrm{sec}^{-1}\right)$, bottom water velocity ( $2 \mathrm{~cm}$ above substrate, $\mathrm{cm} \mathrm{sec}^{-1}$ ), water depth $(\mathrm{cm})$ and substrate composition. Water velocity was measured with a flow meter (Marsh-McBirney Flowmate, model 2000). To measure substrate, a grid of $255 \times 5$-cm cells was centered over each location, and the dominant substrate size class for each cell was recorded. Substrate size, measured across the longest axis, was classed as the average value of 10 ranges: $0.032 \mathrm{~mm}$ (silt, range $0.004-0.06$ 
$\mathrm{mm}$ silt); $1.0 \mathrm{~mm}$ (sand, range $>0.06-2 \mathrm{~mm}) ; 0.5 \mathrm{~cm}$ (range $>0.02-1 \mathrm{~cm}) ; 2 \mathrm{~cm}($ range $>1-3 \mathrm{~cm})$; $4 \mathrm{~cm}$ (range $>3-5 \mathrm{~cm}) ; 7.5 \mathrm{~cm}($ range $>5-10 \mathrm{~cm}) ; 12.5 \mathrm{~cm}($ range $>10-15 \mathrm{~cm}) ; 17.5 \mathrm{~cm}($ range $>15-20 \mathrm{~cm}) ; 22.5 \mathrm{~cm}($ range $>20-25 \mathrm{~cm})$; and $30 \mathrm{~cm}(>25 \mathrm{~cm}$ ). The mean of the 25 scores (from the $255 \times 5-\mathrm{cm}$ cell grid) produced a substrate size index for each location. Substrate heterogeneity at each location was determined using the standard deviation of the mean of the 25 substrate values (Bain 1985).

\section{Habitat Use}

Habitat use data were obtained from underwater observations (snorkeling) within run and riffle habitats at Spread (13 and 20 Sept 2002), Whetstone (11 Aug 2004) and Ivydale (1 Sept 2004). While snorkeling in an upstream direction during daylight hours (9:00-15:00 h), we marked spotted darter locations using numbered weighted tags. Darter locations were not marked if the presence of divers noticeably altered fish behavior. Mean water velocity (60\% of

depth, $\left.\mathrm{cm} \mathrm{sec}^{-1}\right)$, bottom water velocity $\left(2 \mathrm{~cm}\right.$ above substrate, $\left.\mathrm{cm} \mathrm{sec}^{-1}\right)$, water depth $(\mathrm{cm})$ and substrate composition were measured at each fish location (as described above for habitat availability).

\section{Data Analysis}

We explored within- and among-site patterns of habitat availability and microhabitat use with principle components analysis (PCA). Specifically, we explored microhabitat availability within and among riffle and run habitats. Additionally, we examined relationships between microhabitat availability and microhabitat use within riffle and run habitats at each site. Before PCA, nonnormal data of habitat availability and habitat use were $\log (x+1)$ transformed. Separate plots of PC1 x PC2 depicted dissimilarities of: (1) habitat availability between riffle 
and run sites, among run sites, and between riffle sites; and (2) between habitat availability and habitat use within each site. Varimax rotation increased interpretation of principal components (McGarigal et al. 2000). For each PC1 x PC2 plot, we used multivariate analysis of variance (MANOVA) to determine if clusters of groups were significantly $(\mathrm{P}<0.05)$ different. An ANOVA and Tukey-Kramer test (for $>2$ groups) or Student's t-test (for 2 groups) were used to determine differences along each PC axis, if clusters were significantly different along one axis independent of the second axis. Means and standard errors of habitat variables aided interpretation of PCA. All statistical tests were conducted with SAS software.

\section{Results}

\section{Habitat availability}

Habitat availability between riffle and run habitats differed significantly (MANOVA, $\mathrm{F}_{(2}$, 168) $=18.92, \mathrm{p}<0.05 ;$ Figure 2, Table 1) where water velocities within riffles exceeded those of run habitats $\left(\mathrm{PC} 1\right.$, Student's t-test, $\left.\mathrm{t}_{(159)}=5.19, \mathrm{p}<0.05\right)$ and substrate size and substrate heterogeneity within run habitats exceeded those of riffles (PC2, Student's t-test, $\mathrm{t}_{(147)}=4.16$, $\mathrm{p}<0.05)$. A PCA depicted significant differences in habitat availability among run habitats (MANOVA, $\mathrm{F}_{(4,222)}=16.85$, $\mathrm{p}<0.05$; Figure 3, Table 1). An ANOVA and Tukey-Kramer test indicated that water velocities at Whetstone and Spread were significantly faster than those of Ivydale $\left(\mathrm{PC} 1, \operatorname{ANOVA}, \mathrm{F}_{(2,111)}=22.89, \mathrm{p}<0.05\right)$, and substrate size and heterogeneity values at Ivydale were significantly larger than those at Whetstone and Spread $\left(\mathrm{PC} 2\right.$, ANOVA, $\mathrm{F}_{(2,111)}=$ 11.67, $\mathrm{p}<0.05$ ); however, water depths were similar among run habitats (Table 1). For riffle habitats, water depth at Whetstone was shallower than that of Ivydale (Table 1). Based on PCA, 
substrate size and heterogeneity within the Whetstone riffle exceeded that of the Ivydale riffle $\left(\mathrm{PC} 1\right.$, Student's t-test, $\mathrm{t}_{(48)}=3.96, \mathrm{p}<0.05$, Figure 4).

\section{Habitat use}

At Ivydale and Whetstone, the number of spotted darter observations in run habitats (32 and 26) exceeded those in riffle habitats (10 and 7), respectively. At Spread, spotted darters were absent in the riffle, but 35 were observed in the run habitat. In addition to differences in habitat use between run and riffles, spotted darters were associated with larger rocks $(>20 \mathrm{~cm}$ diameter), greater substrate heterogeneity, and faster velocities in run habitats. Large rocks were an important component of spotted darter habitat (Table 1); out of 111 total observations, 69 and 100 spotted darters were near or under rocks $>25 \mathrm{~cm}$ and $>20 \mathrm{~cm}$ diameter, respectively.

Within the $25 \mathrm{~cm}^{2}$ scale of observation, average rock sizes used by spotted darters among sites ranged from 12.4 to $18.2 \mathrm{~cm}$ (Table 1). Despite differences in available habitats among run and riffle sites, spotted darters were associated with rocks of similar size among sites, except for smaller rocks at the Ivydale riffle.

\section{Within site habitat use versus habitat availability}

For run habitats at Spread and Whetstone, the cluster of principal components of habitat use differed significantly from that of habitat availability (MANOVAs, $\mathrm{F}_{(2,89)}=13.27$, $\mathrm{p}<0.05$, and $\mathrm{F}_{(2,51)}=35.65, \mathrm{p}<0.05$, respectively) where substrate heterogeneity and substrate size associated with spotted darters exceeded that of habitat availability (PC1, Student's t-tests, $\mathrm{t}_{(88)}=$ 5.11, $\mathrm{p}<0.05$, and $\mathrm{t}_{(46)}=5.36, \mathrm{p}<0.05$, respectively; Figures 5 and 6 ). Spotted darters used deeper areas and faster velocities in the run at Whetstone (PC2, Student's t-test, $\mathrm{t}_{(36)}=3.96, \mathrm{p}<0.05$; Figure 6). For the run habitat at Ivydale, clusters of habitat use and habitat availability did not 
differ significantly (MANOVAs, $\mathrm{F}_{(2,59)}=2.09, \mathrm{p}>0.05$, Figure 7). Univariate analyses supported the interpretation of PCA; however, in addition to larger substrate sizes and higher substrate heterogeneity, mean water velocity and bottom velocity of habitat use data consistently exceeded that of availability within run habitats (Table 1). For riffle habitats at Whetstone and Ivydale, habitat use differed significantly from that of habitat availability (MANOVAs, $\mathrm{F}_{(2,33)}=$ $24.34, \mathrm{p}<0.05$, and $\mathrm{F}_{(2,35)}=50.05, \mathrm{p}<0.05$, respectively) where substrate heterogeneity and substrate size associated with spotted darters exceeded that of habitat availability (PC1, Student's t-test, $\mathrm{t}_{(33)}=12.59, \mathrm{p}<0.05$, and PC2, Student's t-test, $\mathrm{t}_{(23)}=3.94, \mathrm{p}<0.05$, respectively; Figures 8 and 9). Also, water velocities associated with spotted darters within the Ivydale riffle were significantly slower than those of habitat availability data (PC1, Student's t-test, $\mathrm{t}_{(11)}=4.73$, $\mathrm{p}<0.05)$.

\section{Discussion}

Darters are adapted morphologically for a wide range of substrates and velocities (Page 1983, Page \& Swofford 1984) and habitat use is documented for many species (Matthews 1985, Hlohowskyj \& Wissing 1986, Chipps et al. 1994, Welsh \& Perry 1998), including spotted darters (Kessler \& Thorp 1993, Stauffer et al. 1996). Within run habitats of the middle section of Elk River, large unembedded substrate (> $20 \mathrm{~cm}$ ) and moderate velocities ( 13 to $51 \mathrm{~cm} \mathrm{sec}^{-1}$ ) were important habitat for spotted darters. Few spotted darters were observed in riffle habitats, a finding inconsistent with most reports of spotted darter habitat use (Trautman 1981, Burr \& Warren 1986, Kessler \& Thorp 1993, Stauffer et al. 1996). Run habitats within our study area had lower bottom and mean velocities, larger rock size and higher substrate heterogeneity than 
riffle habitats. Use of slower velocity run habitats by spotted darters in the Elk River may be associated with availability of larger rocks, where individuals avoid riffles with smaller substrate.

Spotted darters in the Elk River were associated with large rocks $(>20 \mathrm{~cm})$, a finding consistent among our results and those of previous studies (Kessler \& Thorp 1993, Stauffer et al. 1996). Average sizes of rocks used by Elk River spotted darters were significantly larger than those of available habitat, except for the run at Ivydale where large rocks were distributed uniformly. We quantified habitat during low flows of summer and early fall; however, large substrate is also of primary importance to spotted darters for nest sites and egg attachment during spring spawning (Raney \& Lachner 1939).

Although researchers have also documented swift riffles as primary habitat of spotted darters (Raney \& Lachner 1939, Baker et al. 1985, Burr \& Warren 1986, Kessler et al. 1995, Stauffer et al. 1996), we found most Elk River spotted darters in run habitat, and few in riffle habitat. Suitable run habitats within the middle section of Elk River were primarily located in the transition between slow pool and swift riffle habitat. Average velocity of spotted darter locations in run habitats was generally higher than that of available habitat. In the Elk River, spotted darters may associate with relatively high velocity areas of run habitats, in part, because of an absence of silt. Kessler \& Thorp (1993) reported that spotted darters were not associated with silt-covered substrates, possibly because the substrates may also be used as spawning sites.

\section{Management Implications}

Many darters exhibit specific habitat requirements and are often threatened by habitat alterations (e.g.: Connelly et al. 1999, Mattingly and Galat 2002) because habitat specialists have higher vulnerability to habitat alterations. Specialization of habitat use of spotted darters often 
surpasses that of coexisting species (Kessler \& Thorp 1993, Stauffer et al. 1996) thereby allowing spotted darters to be more easily displaced than habitat generalists. Kessler \& Thorp (1993) noted that sedimentation reduces the availability of "large, loose, rough substrate" used by spotted darters. Clean cavities under large rocks are important spawning areas for spotted darters (Raney \& Lachner 1939). Egg aeration uninhibited by large amounts of sediment is likely an important factor for recruitment. Large rocks also likely act as refuge from predation and velocity shelters (Harding et al. 1998), as spotted darters are observed under these substrates outside of reproductive seasons (Kessler \& Thorp 1993).

Sedimentation associated with land use practices threatens darter habitat, including spotted darter habitat, as it fills interstitial spaces (Mattingly and Galat 2002). Within the Elk River watershed, sedimentation results from many sources, including logging, coal mining, and oil and gas extraction $\left(\right.$ WVDEP$\left.^{2}\right)$ and may threaten spotted darter habitat. Management actions can reduce negative impacts to sensitive darter species such as protection of riparian areas (Jones et al. 1999) or entire watersheds (Freeman and Freeman 1994). Substrate specificity of Elk River spotted darters, supported by our observational study, not only imparts management and conservation implications, but also provides baseline for further experimental studies of spotted darter habitat use.

\footnotetext{
${ }^{2}$ West Virginia Department of Environmental Protection (WVDEP). 1997. An Ecological Assessment of the Elk River Watershed. WVDEP, Division of Water Resources, Water Assessment Program website: http://www.wvdep.org/Docs/474_EAoftheElkRvrWatershed.pdf
} 


\section{Acknowledgements}

We thank L. Hedrick, H. Hildebrand, Z. Liller, K. Sheehan, and D. Wellman for assistance with data collection. Financial support for this project was provided by West Virginia Division of Natural Resources and the U.S. Fish and Wildlife Service. 


\section{References}

Bain, M. B. 1985. Quantifying stream substrate for habitat analysis studies. N. Amer. J. Fish. Manag. 5: 499-506.

Baker, C., B. Forsyth, T. Wiles, and D. B. Abrell. 1985. Rediscovery of the spotted darter, Etheostoma maculatum, in Indiana waters: Blue River; Crawford, Harrison and Washington Counties; Ohio River Drainage, USA. Indiana Acad. of Sci. 94: 603-605.

Burr, B. M. and M. L. Warren, Jr. 1986. Distributional Atlas of Kentucky Fishes. Kentucky Nature Preserves Commission, Frankfort. 398 pp.

Chipps, S. R., W. B. Perry, and S. A. Perry. 1994. Pattern of microhabitat use among four species of darters in three Appalachian streams. Am. Midl. Nat. 131: 175-180.

Cincotta, D. A., R.L. Miles, M. E. Hoeft, and G. E. Lewis. 1986. Discovery of Noturus eleutherus, Noturus stigmosus and Percina peltata in West Virginia, with discussions of other additions and records of fishes. Brimleyana 12: 101-121.

Connelly, W. J., D. J. Orth, R. K. Smith. 1999. Habitat of the riverweed darter, Etheostoma podostemone Jordan, and the decline of riverweed, Podostemum ceratophyllum, in the tributaries of the Roanoke River, Virginia. J. Freshwat. Ecol. 14: 93-102.

Etnier, D.A. 1980. Etheostoma maculatum Kirtland Spotted darter. p. 664. In: Lee, D. S., C. R. Gilbert, C. H. Hocutt, R. E. Jenkins, D. E. McAllister, J. R. Stauffer, Jr. editors, Atlas of North American Freshwater Fishes. N.C. State Mus. Nat. Hist., Raleigh. 867 pp.

Freeman, B. J. and M. C. Freeman. 1994. Habitat use by an endangered riverine fish and implications for species protection. Ecol. of Freshwat. Fish 3: 49-58.

Harding, J. M., A. J. Burky, and C. M. Way. 1998. Habitat preferences of the rainbow darter, Etheostoma caeruleum, with regard to microhabitat velocity shelters. Copeia 1998: 988-997.

Hlohowskyj, I. and T. E. Wissing. 1986. Substrate selection by fantail (Etheostoma flabellare), greenside (E. blennioides) and rainbow (E. caeruleum) darters. Ohio J. Sci. 86(3): 124-129.

Jones, E. B. D., G. S. Helfman, J. O. Harper, \& P. V. Bolstad. Effects of riparian forest removal on fish assemblages in southern Appalachian streams. Con. Biol. 13: 1454-1465.

Kessler, R. 1994. Diet of the spotted darter, Etheostoma maculatum (Pisces: Percidae): A threatened species in Kentucky. Trans. Ky. Acad. of Sci. 55: 28-31.

Kessler, R. K. and J. H. Thorp. 1993. Microhabitat segregation of the threatened spotted darter (Etheostoma maculatum) and closely related orangefin darter (E. bellum). Can. J. Fish. Aquat. Sci. 50: 1084-1091. 
Kessler, R., A. Casper, G. Weddle 1995. Temporal variation in microhabitat use and spatial relations in the benthic fish community. Amer. Midl. Nat.134: 361-370.

Mattingly, H. T. and D. L. Galat. 2002. Distributional patterns of the threatened Niaguana darter, Etheostoma nianguae, at three spatial scales, with implications for species conservation. Copeia 2002: 573-585.

Matthews, W. J. 1985. Critical current speeds and microhabitats of the benthic fishes Percina roanoka and Etheostoma flabellare. Environ. Biol. Fish. 12:303-308.

McGarigal, K., S. Cushman, and S. Stafford. 2000. Multivariate Statistics for Wildlife and Ecology Research. Springer-Verlag, New York. 283 pp.

Page, L. M. 1983. Handbook of Darters. TFH Publications, Neptune City, NJ. 271 pp.

Page, L.M. and D.L. Swofford. 1984. Morphological correlates of ecological specialization in darters. Environ. Biol. Fish. 11:139-159.

Page, L. M. and B. M. Burr. 1991. A Field Guide to Freshwater Fishes of North America North of Mexico. The Peterson Field Guide Series. Houghton Mifflin, Boston. 432 pp.

Raney, E. C. and E. A. Lachner. 1939. Observations on the life history of the spotted darter, Poecilichthys maculatus (Kirtland). Copeia 1939: 157-165.

Simons, A.M. 2004. Phylogenetic relationships in the genus Erimystax (Actinopterygii: Cyprinidae) based on the cytochrome $b$ gene. Copeia 2004: 351-356.

Stauffer, J. R. Jr., J. M. Boltz, L. R. White. 1995. The fishes of West Virginia. Proc. Acad. Nat. Sci. Phil. 146:1-389.

Stauffer, Jr., J. R., J.M. Boltz, K.A. Kellogg, and E.S. van Snik. 1996. Microhabitat partitioning in a diverse assemblage of darters in the Allegheny River system. Environ. Biol. Fish. 46: 3744.

Trautman, M. B. 1981. The Fishes of Ohio. Ohio State University Press, Columbus. 782 pp.

Welsh, S. A. and S. A. Perry. 1998. Habitat partitioning in a community of darters in the Elk River, West Virginia. Environ. Biol. Fish. 51:411-419. 
Tables and Figures 
Table 1. Mean values of habitat availability (A) and habitat use (U) of spotted darters listed by site (standard errors in parentheses).

\begin{tabular}{|c|c|c|c|c|c|c|c|c|}
\hline & $\begin{array}{c}\text { Site } \\
\text { dimensions } \\
\mathrm{L}^{*} \mathrm{~W}(\mathrm{~m})\end{array}$ & $\begin{array}{c}\text { use/ } \\
\text { available }\end{array}$ & $\begin{array}{l}\text { sample } \\
\text { size }\end{array}$ & $\begin{array}{l}\text { depth } \\
(\mathrm{cm})\end{array}$ & $\begin{array}{c}\text { velocity @ } \\
2 \mathrm{~cm}\left(\mathrm{~cm} \mathrm{sec}^{-1}\right)\end{array}$ & $\begin{array}{l}\text { Mean velocity } \\
\quad\left(\mathrm{cm} \mathrm{sec}^{-1}\right)\end{array}$ & $\begin{array}{l}\text { Substrate } \\
\text { size }(\mathrm{cm})\end{array}$ & $\begin{array}{c}\text { Substrate } \\
\text { heterogeneity }\end{array}$ \\
\hline \multicolumn{9}{|l|}{ Run Sites } \\
\hline \multirow[t]{2}{*}{ Spread } & $60 \times 60$ & A & 56 & $37.06(2.92)$ & $14.58(1.36)$ & $35.78(2.42)$ & $11.20(0.55)$ & $6.54(0.38)$ \\
\hline & & $\mathrm{U}$ & 36 & $47.75(2.90)$ & $16.38(1.81)$ & $45.67(3.11)$ & $15.99(0.51)$ & $8.35(0.44)$ \\
\hline \multirow[t]{2}{*}{ Ivydale } & $60 \times 16$ & A & 31 & $35.96(2.81)$ & $3.85(0.83)$ & $13.86(1.36)$ & $14.46(0.99)$ & $8.65(0.41)$ \\
\hline & & $\mathrm{U}$ & 32 & $33.29(1.47)$ & $3.40(0.68)$ & $16.41(1.87)$ & $15.93(0.67)$ & $9.52(0.35)$ \\
\hline \multirow[t]{2}{*}{ Whetstone } & $53 \times 50$ & A & 28 & $33.09(3.11)$ & $12.16(1.52)$ & $31.12(2.42)$ & $9.85(0.49)$ & $5.44(0.35)$ \\
\hline & & $\mathrm{U}$ & 26 & $49.12(1.37)$ & $12.98(1.94)$ & 39.68 (1.19) & $16.23(0.76)$ & $8.22(0.42)$ \\
\hline \multicolumn{9}{|c|}{ Riffle Sites } \\
\hline \multirow[t]{2}{*}{ Ivydale } & $44 \times 24$ & A & 28 & $34.40(1.29)$ & $17.80(1.40)$ & $40.41(2.14)$ & $7.79(0.30)$ & $4.37(0.30)$ \\
\hline & & $\mathrm{U}$ & 10 & $37.18(1.19)$ & $4.30(1.44)$ & $12.89(3.06)$ & $12.38(0.59)$ & $6.57(0.40)$ \\
\hline \multirow[t]{2}{*}{ Whetstone } & $22 \times 52$ & A & 29 & $26.80(2.56)$ & $19.20(2.13)$ & $36.24(3.09)$ & $10.80(0.06)$ & $5.92(0.41)$ \\
\hline & & $\mathrm{U}$ & 7 & $31.78(3.93)$ & $19.20(5.47)$ & $51.51(4.63)$ & $18.17(1.73)$ & $11.01(0.83)$ \\
\hline
\end{tabular}


Figure 1. Location of sampling sites $(\bullet)$ of spotted darter habitat use within the Elk River of the lower Kanawha River system, West Virginia

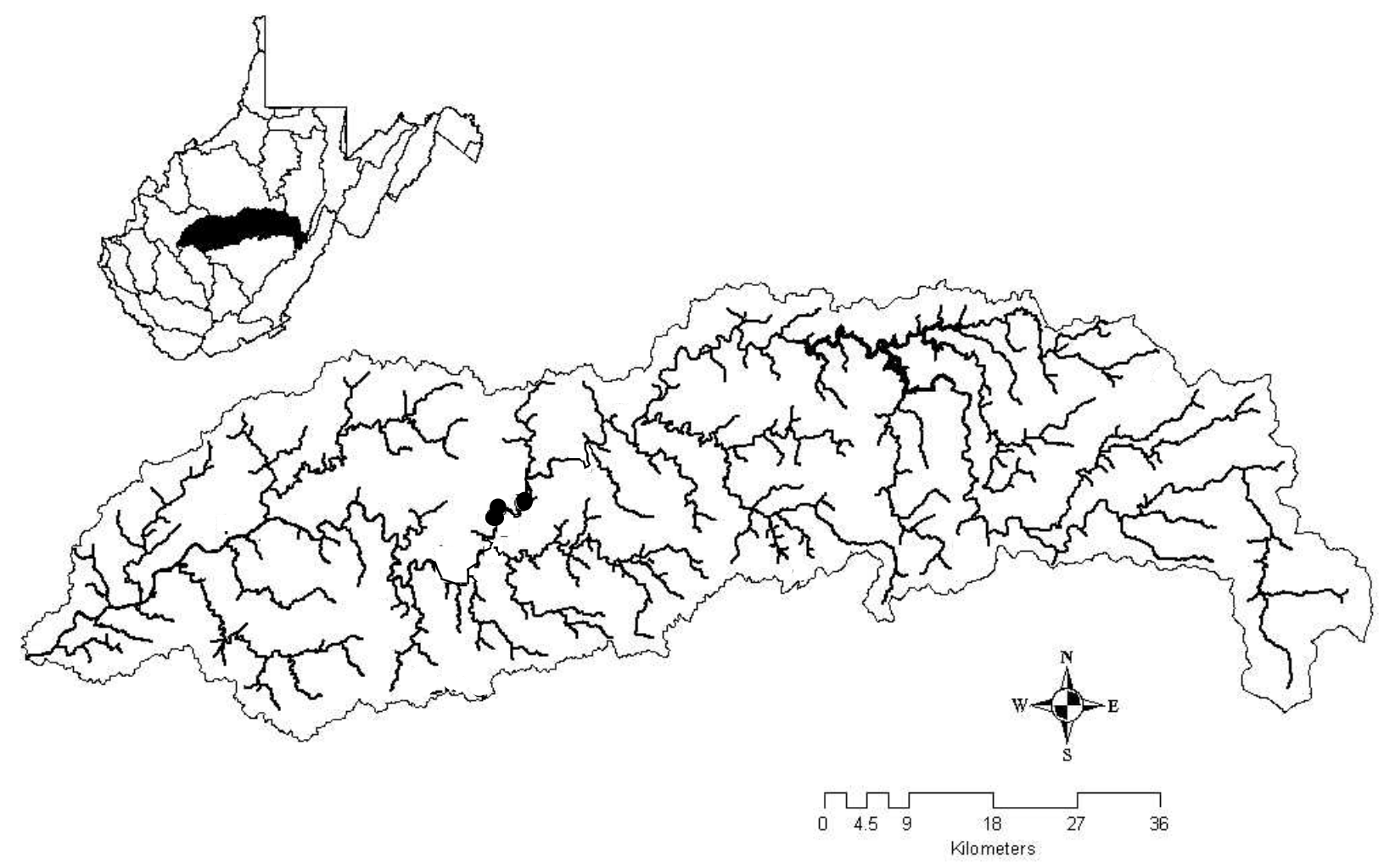


Figure 2. PCA-ordination diagram of habitat availability data from run (0) and riffle $(\bullet)$ habitats.

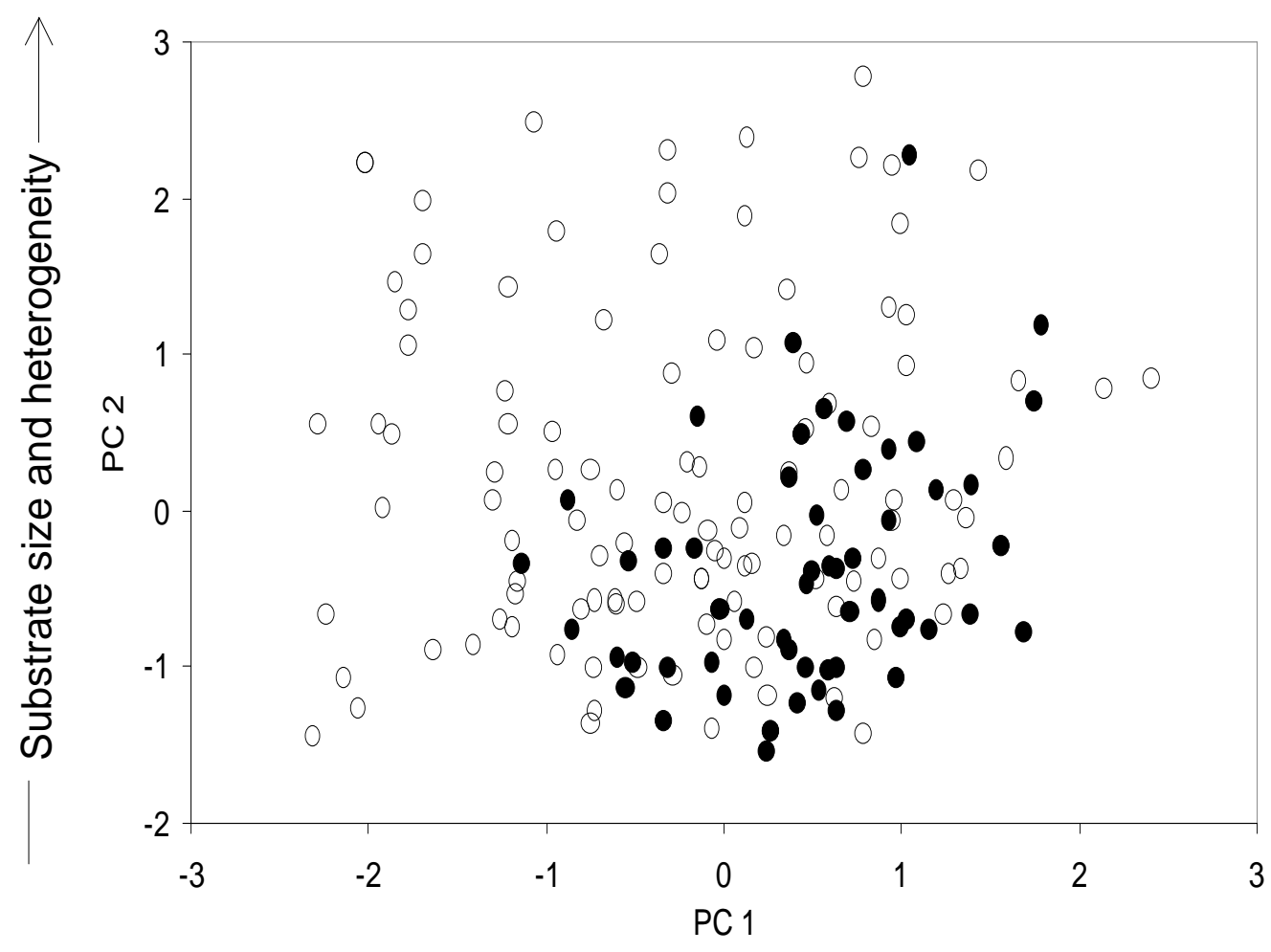

Bottom and mean velocity 
Figure 3. PCA-ordination diagram of habitat availability data from runs; Ivydale (0), Whetstone $(\bullet)$, and Spread $(\mathbf{\Lambda})$.

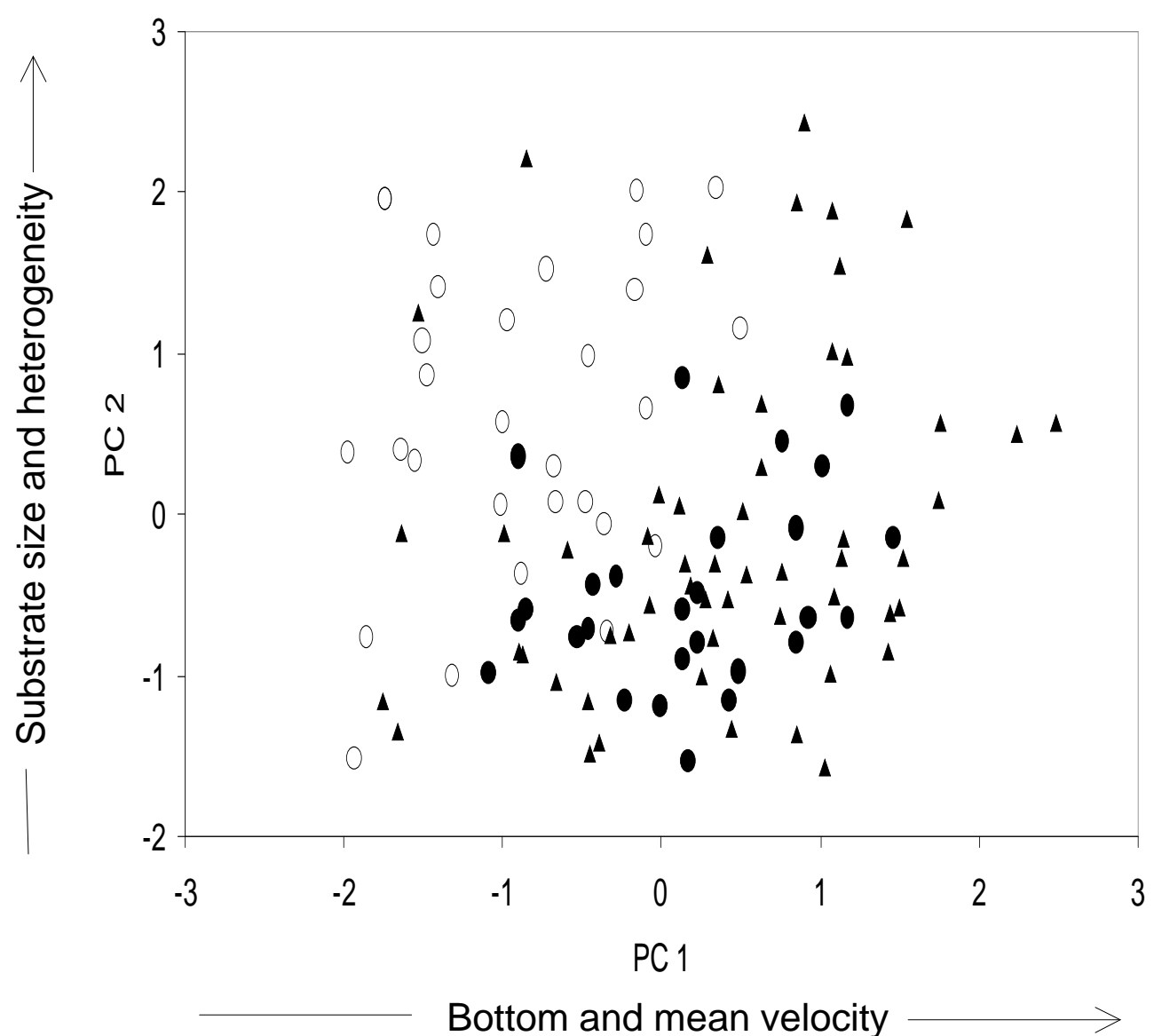


Figure 4. PCA-ordination diagram of habitat availability data from riffles; Ivydale (0), and Whetstone $(\bullet)$.

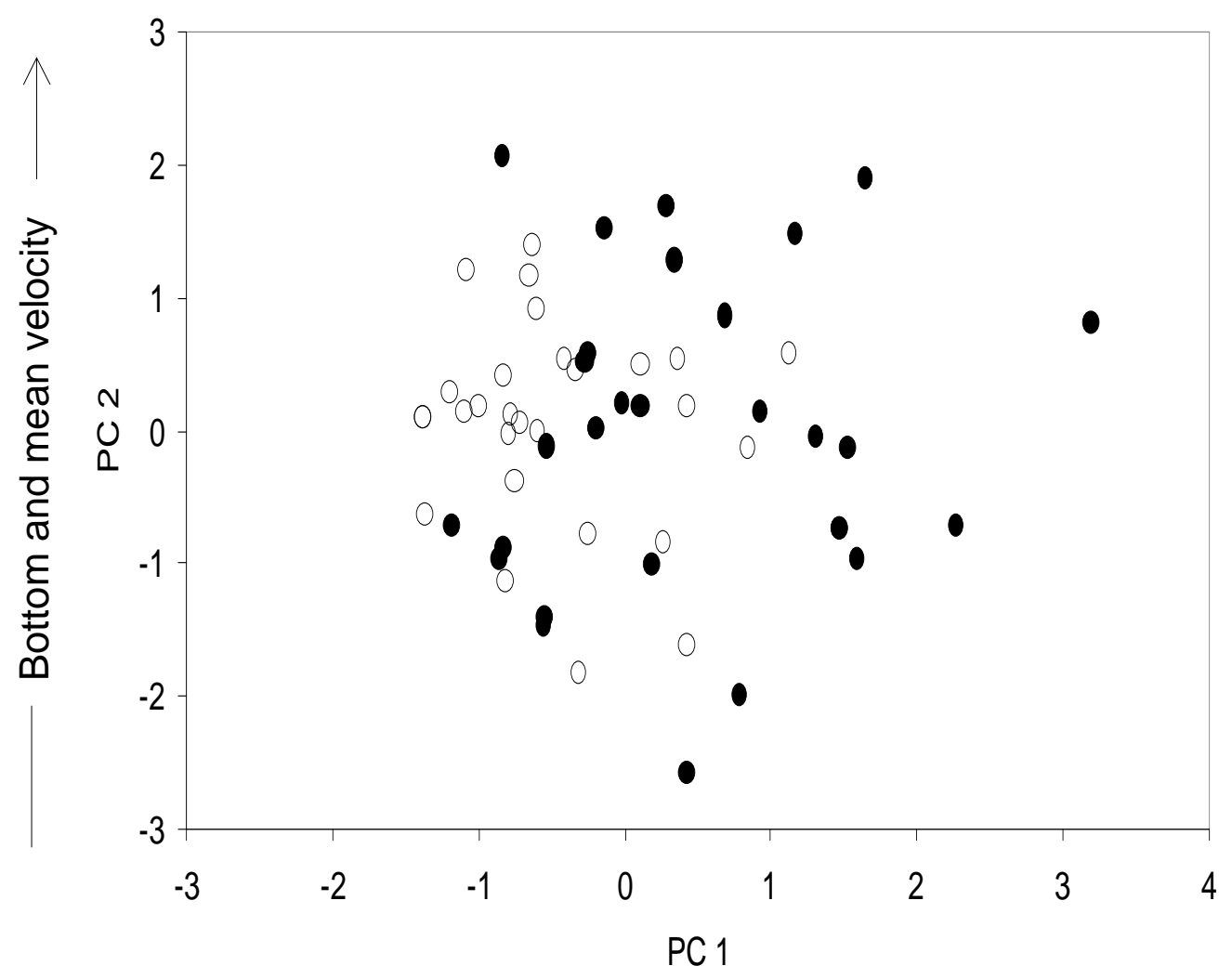

Substrate size and heterogeneity 
Figure 5. PCA-ordination diagram of habitat use $(\bullet)$ of spotted darters versus habitat availability (0) from the run habitat at Spread, West Virginia.

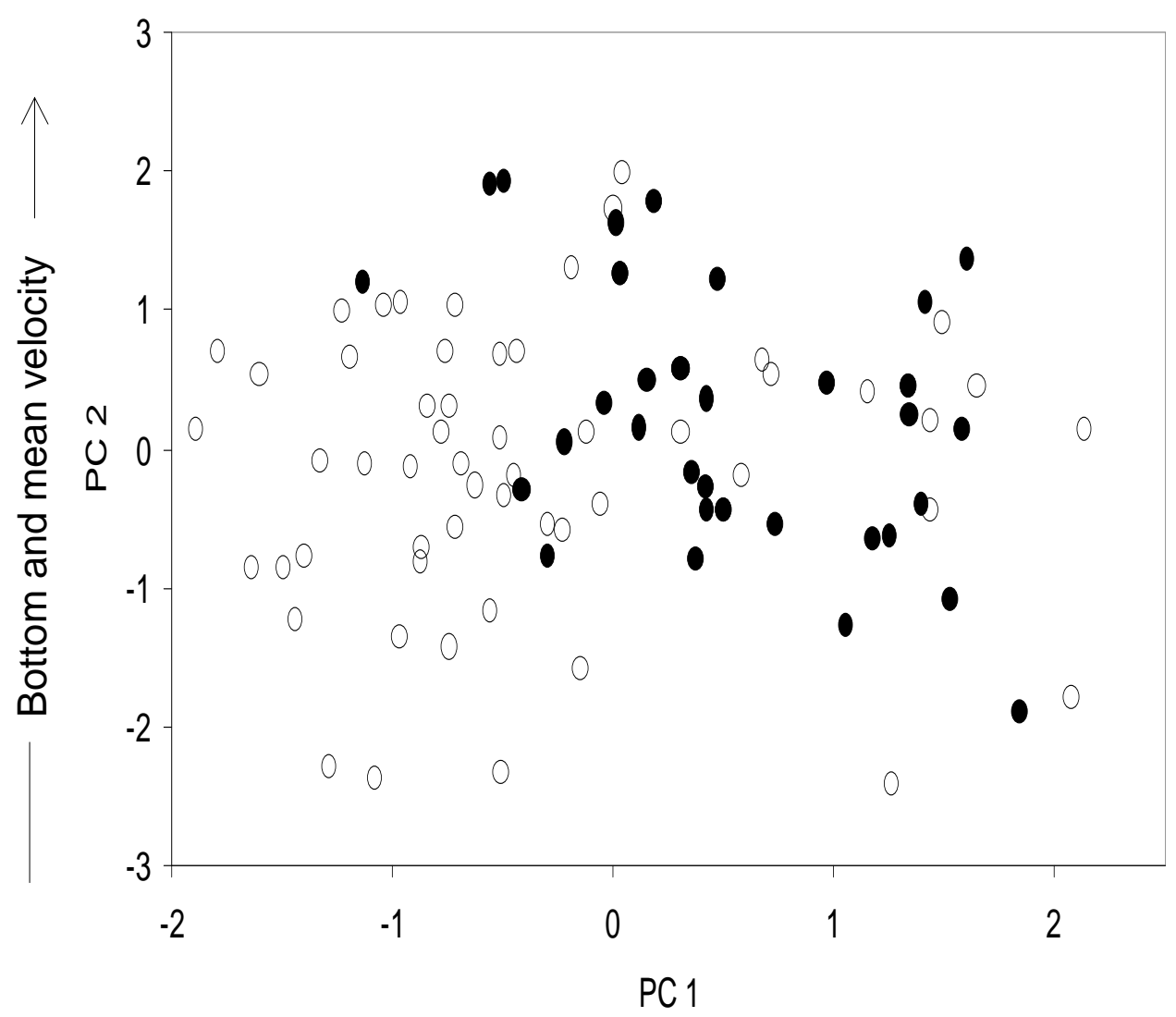

Substrate size and heterogeneity 
Figure 6. PCA-ordination diagram of habitat use $(\bullet)$ of spotted darters versus habitat availability (0) from the run habitat at Whetstone, West Virginia.

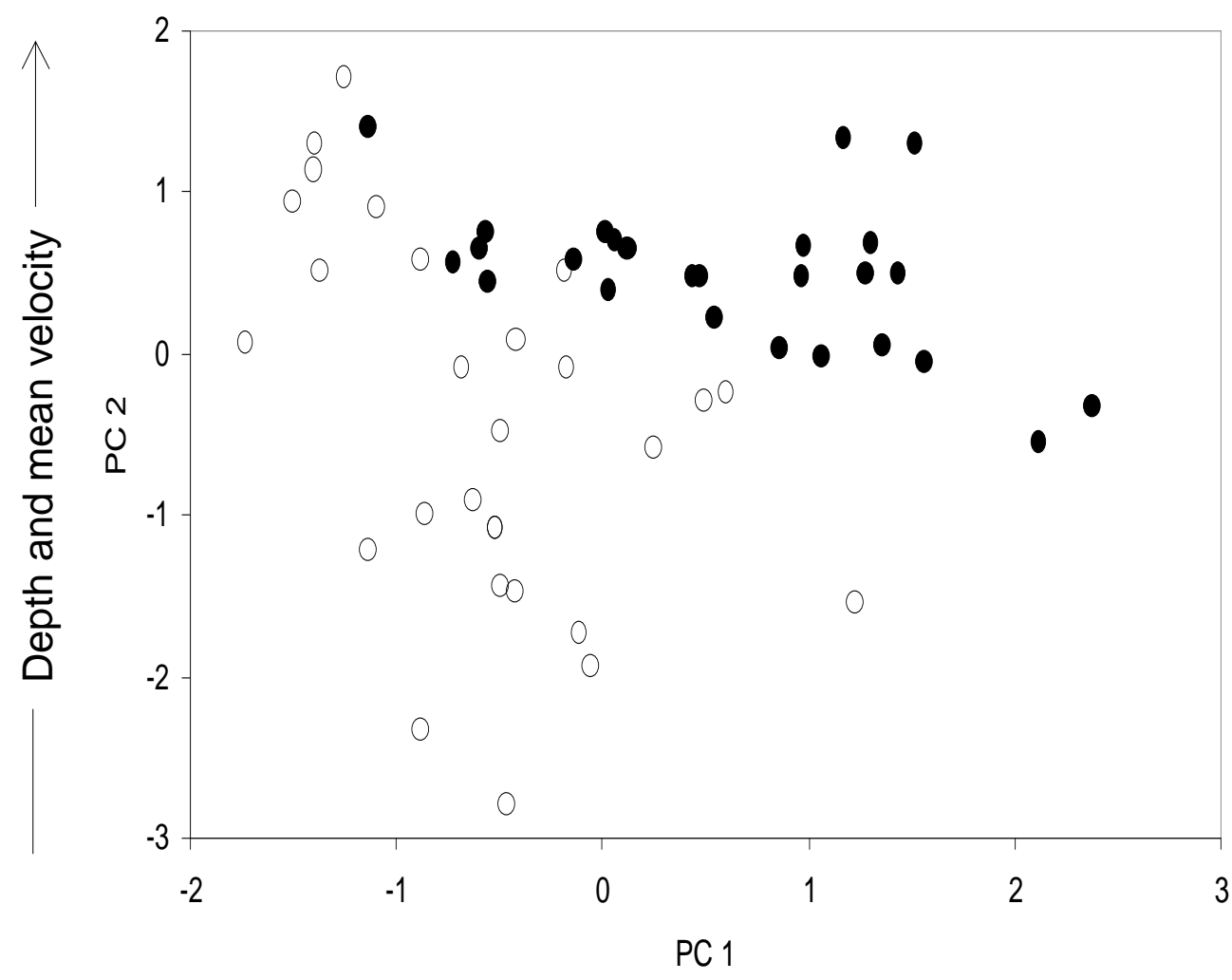

Substrate size and heterogeneity 
Figure 7. PCA-ordination diagram of habitat use $(\bullet)$ of spotted darters versus habitat availability (0) from the run habitat at Ivydale, West Virginia.

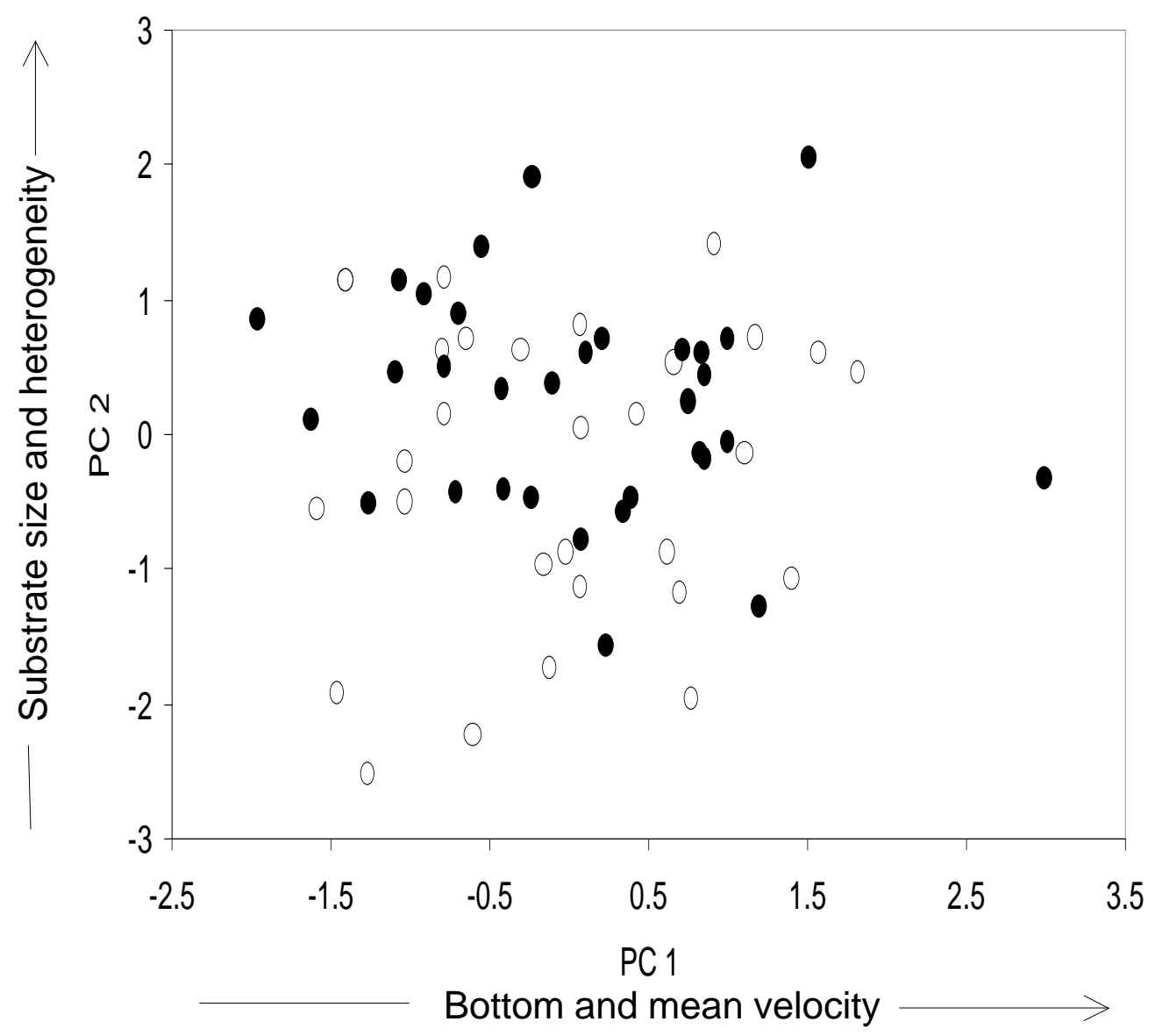


Figure 8. PCA-ordination diagram of habitat use $(\bullet)$ of spotted darters versus habitat availability (0) from the riffle habitat at Whetstone, West Virginia.

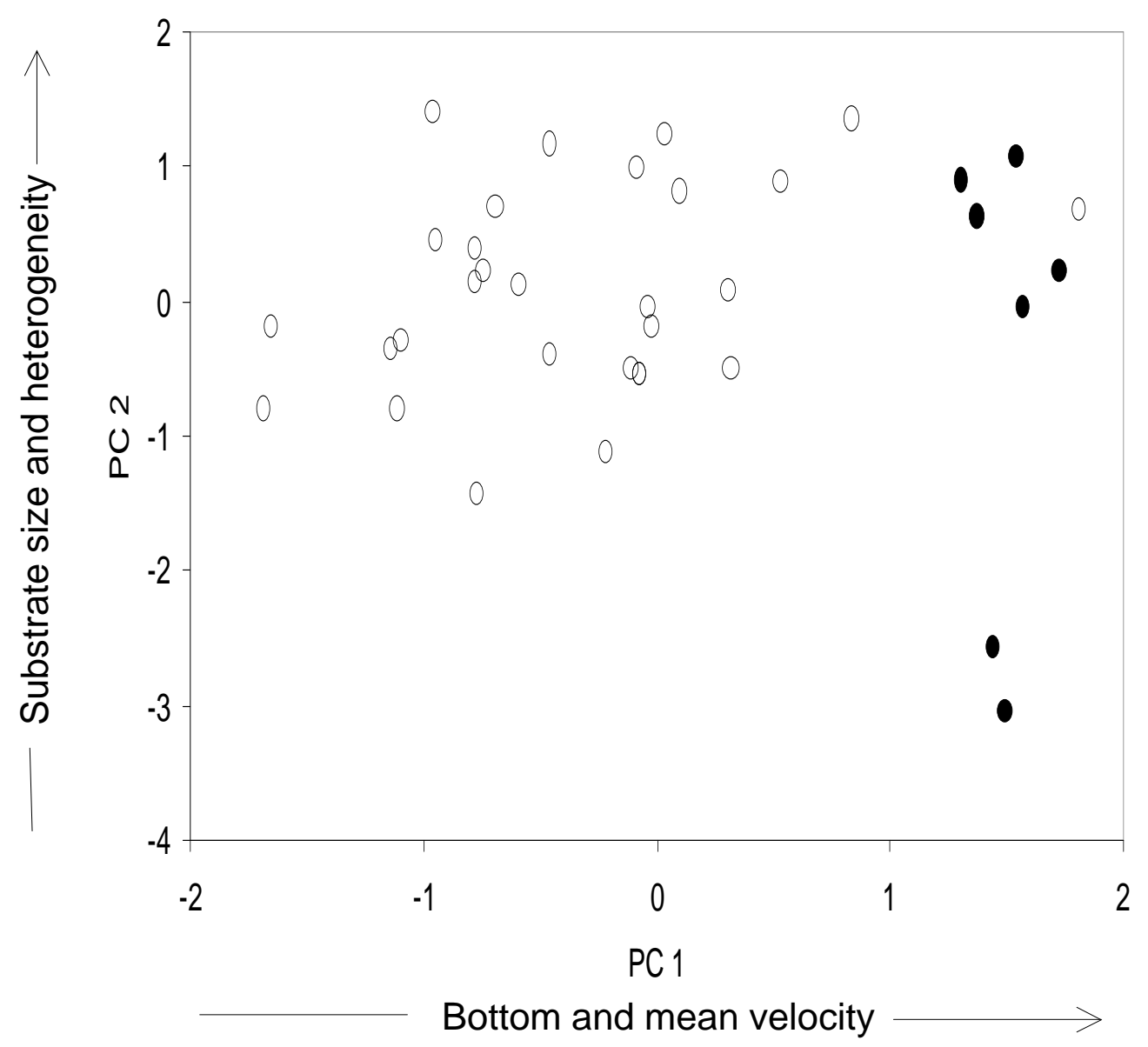


Figure 9. PCA-ordination diagram of habitat use $(\bullet)$ of spotted darters versus habitat availability (0) from the riffle habitat at Ivydale, West Virginia.

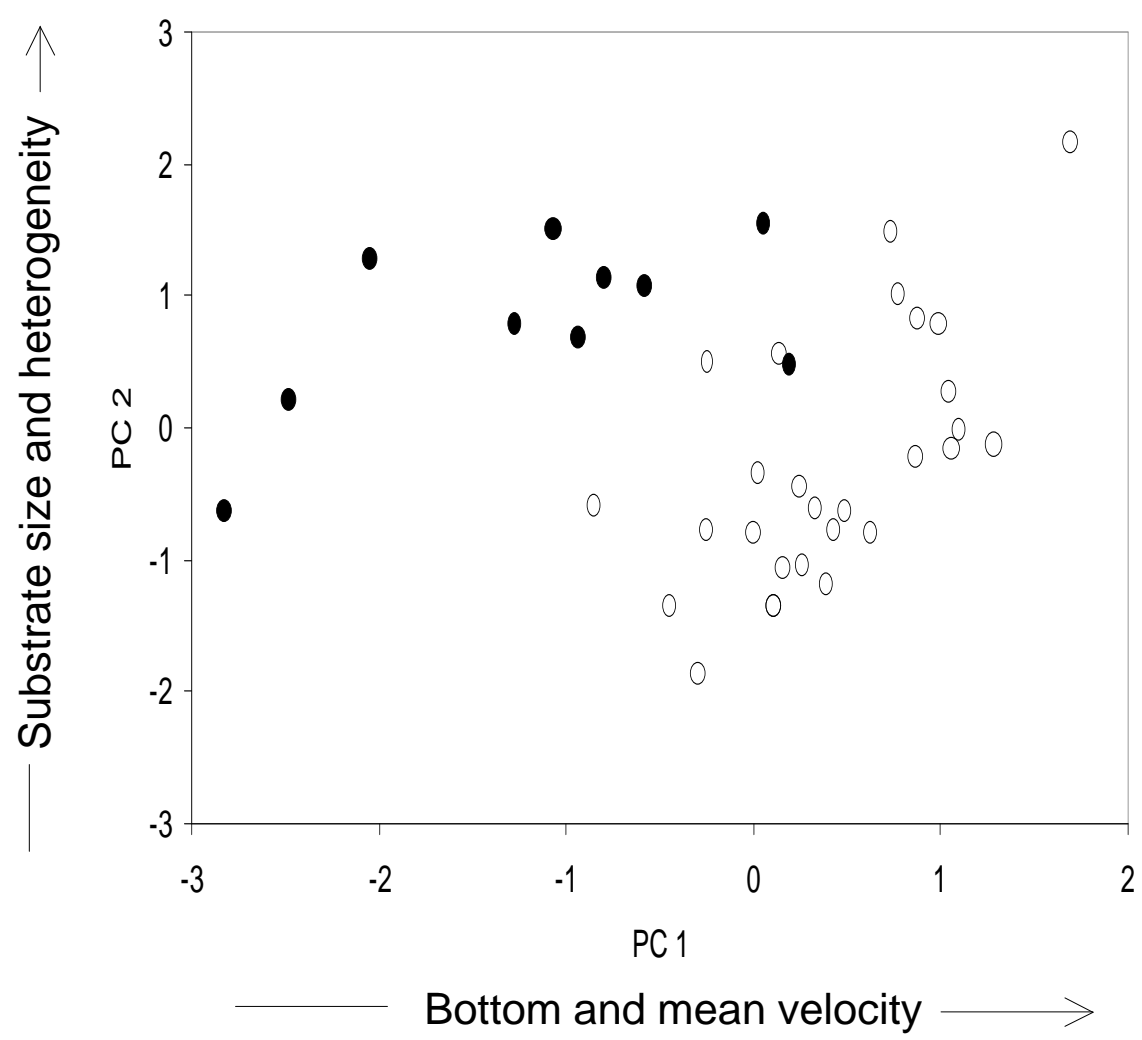


Appendix 1. Distribution of extant (circles) and possibly extirpated (square) populations of spotted darters in the Elk River, West Virginia. Open circles depict sites from the habitat use study.

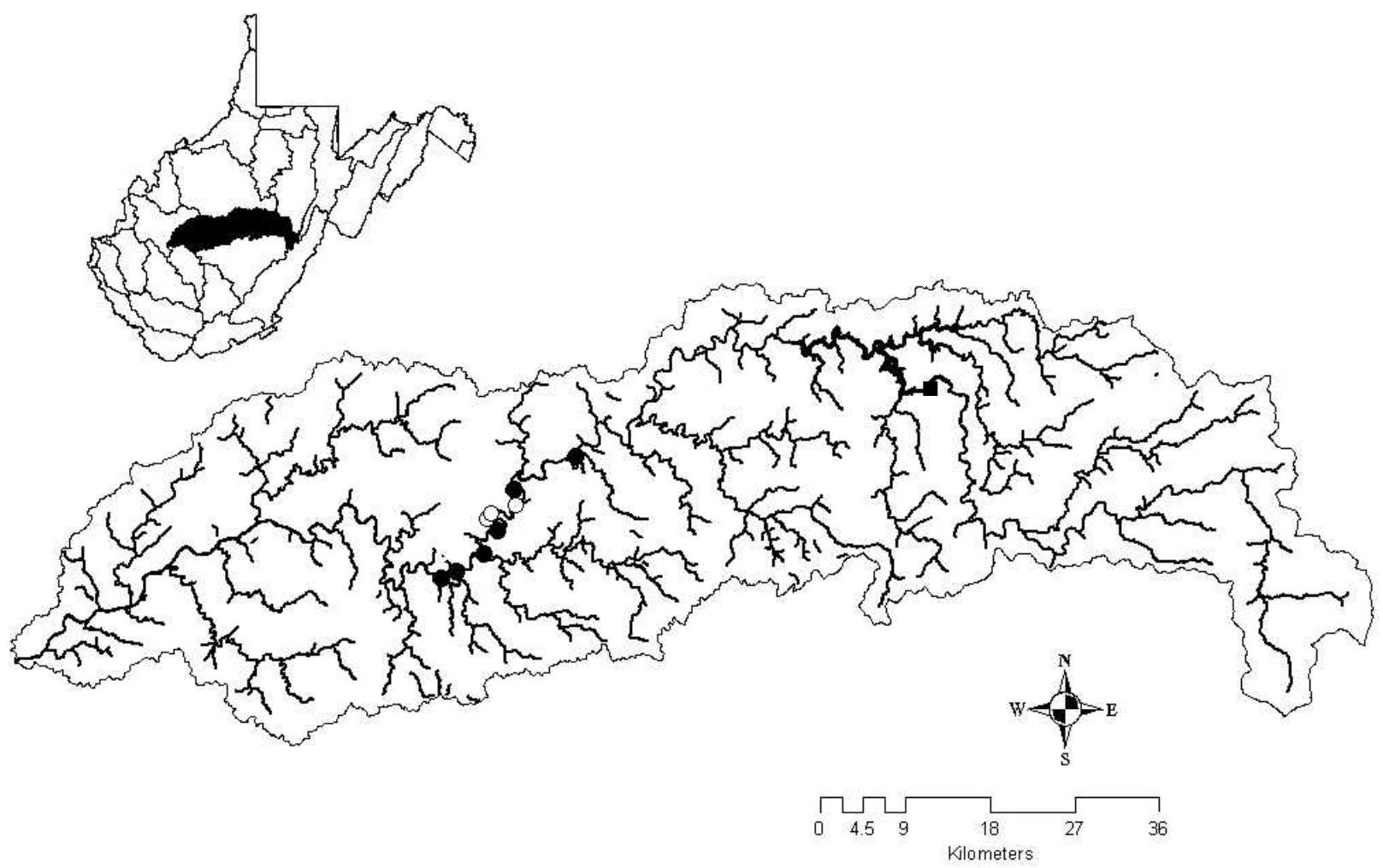

